\title{
Acute Infectious Diseases
}

\author{
Erich Schmutzhard and Bettina Pfausler
}

\section{Contents}

14.1 Introduction. . . . . . . . . . . . . . . . . . . . . . . . . . . . . . . . . 177

14.2 Acute Viral Diseases of the Nervous System . . . . . . . . . . . . . . . . . . . . 177

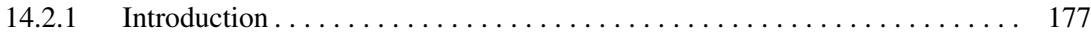

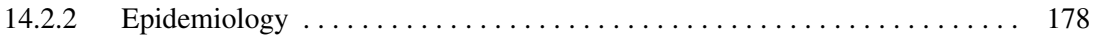

14.2.3 Pathogenesis and Pathophysiology ...................... 178

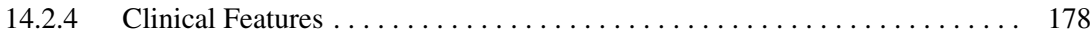

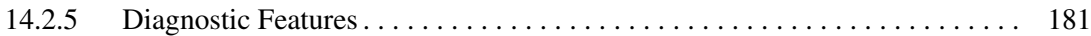

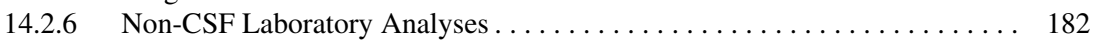

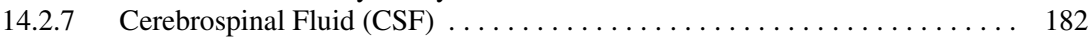

14.2.8 Differential Diagnosis . . . . . . . . . . . . . . . . . . . . . . . . . . . . 182

14.2.9 Therapeutic Management . . . . . . . . . . . . . . . . . . . . . . . 182

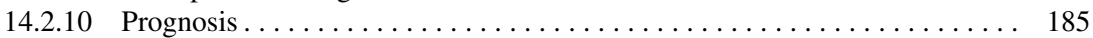

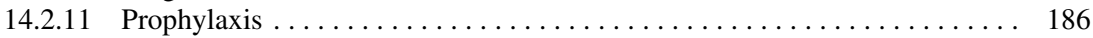

14.3 Acute Bacterial Meningitis . . . . . . . . . . . . . . . . . . . . . . . 186

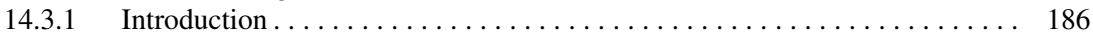

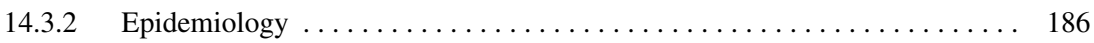

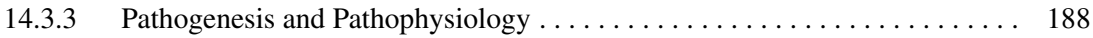

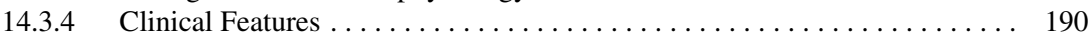

14.3.5 Diagnostic Features. . . . . . . . . . . . . . . . . . . . . . . 192

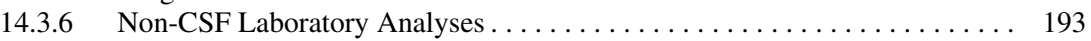

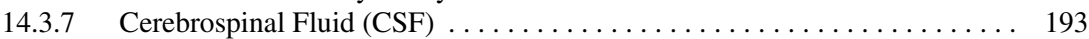

14.3.8 Differential Diagnosis . . . . . . . . . . . . . . . . . . . . . . . 194

14.3.9 Therapeutic Management . . . . . . . . . . . . . . . . . . . . . . . . . . . . 194

14.3.10 Adjunctive Therapies. . . . . . . . . . . . . . . . . . . . . . . . . . . . 197

14.3.11 Prevention ...................................... 198

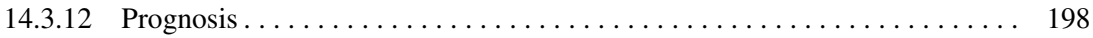

E. Schmutzhard $(\bowtie) \bullet$ B. Pfausler

Neurocritical Care Unit, Department of Neurology,

Innsbruck Medical University,

Innsbruck, Austria

e-mail: erich.schmutzhard@i-med.ac.at 
14.4 Acute Fungal Infections of the Central Nervous System . . . . . . . . . . . . . . . . 198

14.4 .1 Introduction . . . . . . . . . . . . . . . . . . . . . . . . . . . . . 198

14.4.2 Epidemiology..................................... 199

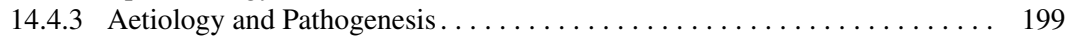

14.4.4 Clinical Features .............................. 200

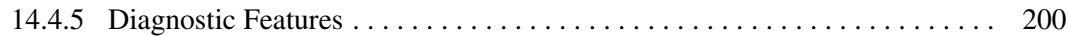

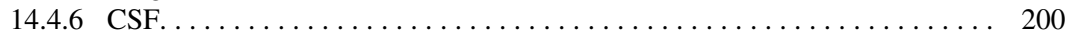

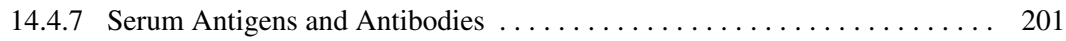

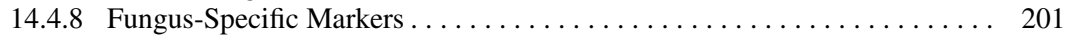

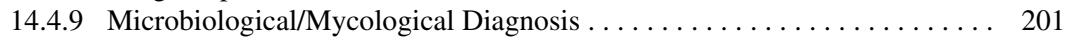

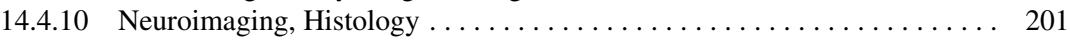

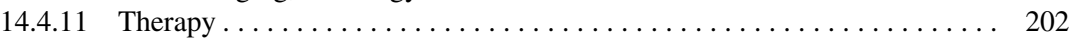

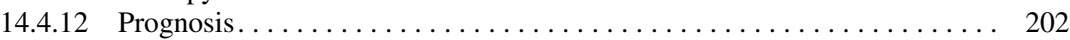

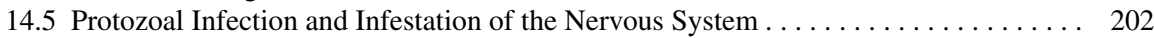

14.5.1 Introduction . . . . . . . . . . . . . . . . . . . . . . . . . . . . 202

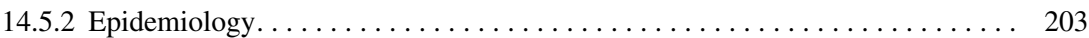

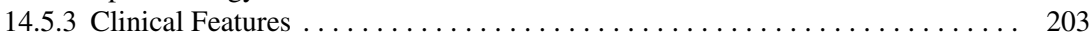

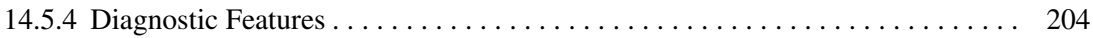

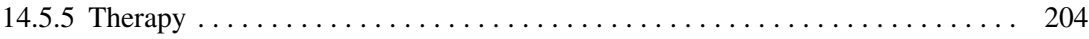

14.6 Helminthic Infections and Infestations of the Central Nervous System. . . . . . . . . 204

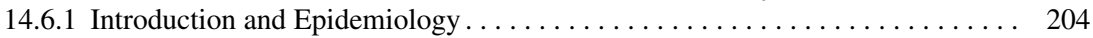

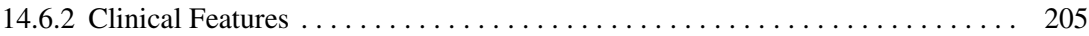

14.6.3 Diagnostic Features . . . . . . . . . . . . . . . . . . . . . . 206

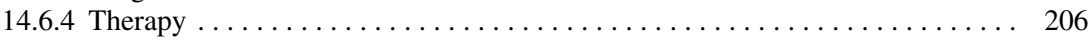

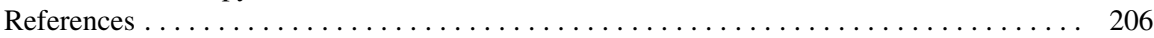

\section{Abstract}

Acute infectious diseases of the nervous system are potentially life threatening, inherently carrying a high long-term morbidity and mortality. Therefore, the earliest possible diagnosis is absolutely essential. Examination of cerebrospinal fluid frequently leads the way towards correct diagnosis and allows for focused antimicrobial and adjunctive therapy. This chapter deals with acute infectious diseases of the nervous system, diagnostic procedures being indispensable. Encephalitis, meningitis, poliomyelitis and polyradiculoneuritis are the most important clinical/neurological entities in case of viral infection. It is the acute bacterial meningitis for which the earliest possible diagnosis carries the most important prognostic implication. For this disease, the appropriate examination of the cerebrospinal fluid (including glucose, cell count, lactate) is of utmost importance. Besides antimicrobial chemotherapy, the best possible adjunctive therapies are essential for acute bacterial meningitis. Fungal, protozoal and helminthic infections of the central nervous system are detailed with respect to diagnostic aspects and therapeutic implications (e.g. eosinophilic meningitis, radiculitis, etc.); for some of these diseases, e.g. cerebral malaria, a normal CSF leads the way to correct diagnosis in a patient with severe impairment of consciousness, high fever and history of exposure to Plasmodium falciparum, thereby easily mistaken for viral encephalitis or acute bacterial meningitis. 


\subsection{Introduction}

Virtually every pathogen can cause disease of the nervous system if it succeeds to traverse the blood-brain barrier (Brouwer et al. 2013a). Besides its inherent pathogenicity, being responsible for the type of disease, the acuteness of disease and the course of disease, but also the anatomical predilection and the anatomically affected region and the systemic as well as the local immune response play a decisive role for clinical presentation, neurological signs and symptoms and eventually the course of disease and prognosis, i.e. morbidity and mortality.

History, epidemiologic features, initial presenting signs and symptoms as well as peracute, acute or subacute evolution of the initial disease are - in a reasonable number of cases - highly suggestive for a suspected pathogen, thus allowing best possible emergency management. As in sepsis syndrome, the earliest possible maximal focused therapy has the most important impact on morbidity and mortality, proven both in acute bacterial meningitis and in sepsis syndrome. Each subchapter contains a short review of epidemiology; discusses etiologic agents, clinical features, diagnostic procedures, in particular, imaging, CSF changes and microbiological findings; discusses specific peculiarities and differential diagnoses; and summarises specific and adjunctive therapies, prognosis and potential preventive measures.

\subsection{Acute Viral Diseases of the Nervous System}

\subsubsection{Introduction}

Each part of the central and peripheral nervous system, even arteries and muscles, may be the target of viral pathogens. Therefore, viruses may cause a wide range of clinical signs and symptoms, as listed in Table 14.1. Viruses may behave differently in the state of immunosuppression or immunocompromise potentially leading to more acute or progressive disease, as seen in progressive multifocal leucoencephalopathy or EBV-associated lymphoproliferative disease. Besides this, post- or

Table 14.1 Clinical features in viral disease of the nervous system (any of any combination is possible)

(Cree 2014; Handique and Handique 2011;

Nigrovic 2013;

Putz et al. 2013; Ross 2014;

Roman 2014)

\begin{tabular}{l}
\hline Meningitis \\
\hline Encephalitis \\
\hline Encephalopathy \\
\hline Myelitis \\
\hline Myelopathy \\
\hline Radiculitis \\
\hline Radiculoneuritis \\
\hline Cranial neuritis \\
\hline Meningovasculitis \\
Myositis (not discussed in this chapter) \\
\hline
\end{tabular}


parainfectious and post-paravaccinal diseases of the central (and also peripheral) nervous system as well as secondary encephalopathy - as seen in influenza virus infection - may be the cause of an even potentially life-threatening disease (Handique and Handique 2011). These secondary diseases of the nervous system are not dealt with in this chapter. Most viruses have specific predilections, causing meningitis or encephalitis or myelitis or any type of combination of the clinical features, listed in Table 14.1.

\subsubsection{Epidemiology}

Many of the viruses causing acute disease of the nervous system can be acquired worldwide, e.g. measles, mumps, coxsackievirus, echovirus, enterovirus, herpesviridae, HIV, lymphocytic choriomeningitis virus, papovavirus, etc. Some of the viruses, in particular those which are acquired by mosquito bite or tick bite, show a clear-cut regional or continental occurrence, e.g. tick-borne encephalitis virus, West Nile virus, Japanese encephalitis virus or other arboviruses. Other viruses which have been the aim of eradication campaigns occur only in well-circumscribed regions, e.g. poliomyelitis virus, enterovirus 68-71, Nipah virus or Zika virus, occurring in certain tropical areas both as epidemics and endemically. Besides the geographic distribution of these various viruses, the way of transmission may play an important epidemiological role (Handique and Handique 2011; Lyons and McArthur 2013). Due to various programmes of eradicating viral diseases by global vaccination campaigns as for measles, mumps and poliomyelitis or regional campaigns to prevent diseases like Japanese encephalitis or tick-borne encephalitis, a changing epidemiology requires the best possible and regular flow of information, i.e. an international surveillance system.

\subsubsection{Pathogenesis and Pathophysiology}

Tables 14.2a, 14.2b and 14.2c list the more important viral causes of acute meningitis, encephalitis, myelitis or any combination of these; in rare cases, meningovasculitis, encephalomyelitis or radiculomyelitis may be caused.

The route of infection differs greatly: enteroviridae being transmitted via the faecooral route, arboviruses - as the name arthropod-borne viruses indicates - are transmitted by mosquitoes or ticks and herpesviridae and most of the other viruses are transmitted via droplet infection, by direct contact and/or exchange of body fluids.

\subsubsection{Clinical Features}

\subsubsection{Viral Meningitis}

The term viral meningitis (lymphocytic/aseptic meningitis used as synonym) is a syndrome with the triad of fever, headache and stiff neck associated with 
Table 14.2a Viral causes of meningitis (Franzen-Rohl et al. 2008; Handique and Handique 2011; Huang and Shih 2014; Nicolasora and Kaul 2008; Nigrovic 2013; Putz et al. 2013)

\begin{tabular}{l}
\hline Enteroviridae \\
\hline Coxsackieviruses A and B \\
\hline Echoviruses \\
\hline $\begin{array}{l}\text { Enteroviruses (Pomar et al. 2013; Postels and Birbeck 2013; Putz et al. 2013; Rodgers } \\
\text { 2010) }\end{array}$ \\
\hline In rare cases: poliomyelitis virus \\
\hline Arboviruses \\
\hline Tick-borne encephalitis virus \\
\hline West Nile virus \\
\hline Japanese encephalitis virus \\
\hline St. Louis encephalitis virus \\
\hline La Crosse virus \\
\hline Western equine encephalitis virus \\
\hline Colorado tick fever virus \\
\hline Dengue viruses \\
\hline Zika viruses \\
\hline Herpesviridae \\
\hline Herpes simplex virus type 2 (in particular relapsing meningitis - Mollaret meningitis) \\
\hline Epstein-Barr virus \\
\hline Varicella zoster virus \\
\hline Human herpes virus 6 (potentially also 7 and 8) \\
\hline Human immunodeficiency virus (after acute infection) \\
\hline Mumps virus \\
\hline Lymphocytic choriomeningitis virus \\
\hline Adenoviruses \\
\hline Arenaviruses \\
\hline Filoviridae \\
\hline Rubella \\
\hline
\end{tabular}

photophobia and possibly signs and symptoms of the autonomic nervous system. It is associated with cerebrospinal fluid lymphocytic pleocytosis. A viral meningitis might evolve into a meningoencephalitis, myelitis, etc.; in these cases, the prognosis is determined by the encephalitic, radiculitic or myelitic part of the disease. A viral meningitis in its pure form has virtually zero mortality and an extremely low longterm morbidity.

\subsubsection{Viral Encephalitis}

The typical clinical presentation of encephalitis is an acute, sometimes subacute condition of fever, headache (frequently holocranial sometimes hemicranial), increasing behavioural abnormalities, mental disturbances, focal or generalised seizure activity, focal or generalised neurological deficits (aphasia, hemiparesis) and 
Table 14.2b Viral causes of encephalitis (De Souza and Madhusudana 2014; Handique and Handique 2011; Kant Upadhyay 2013; Lyons and McArthur 2013; Mann et al. 2013; Misra et al. 2014; Moritani et al. 2014; Nicolasora and Kaul 2008; Ross 2014; Rudolph et al. 2014; Tyler 2014)

\begin{tabular}{l}
\hline Arboviruses \\
\hline Tick-borne encephalitis virus \\
\hline Powassan virus \\
\hline Colorado tick fever virus \\
\hline West Nile virus \\
\hline La Crosse virus \\
\hline St. Louis encephalitis virus \\
\hline Japanese encephalitis virus \\
\hline Yellow fever \\
\hline Dengue virus \\
\hline Equine encephalitis viruses \\
\hline Adenoviruses \\
\hline Herpesviridae \\
\hline Herpes simplex 1 \\
\hline Herpes simplex 2 (in neonates) \\
\hline Varicella zoster virus \\
\hline Epstein-Barr virus \\
\hline Cytomegalovirus (rare in immune competent) \\
\hline Enteroviruses \\
\hline Nipah virus \\
\hline Zika virus \\
\hline Measles virus \\
\hline Rubella virus (very rare) \\
\hline Filoviridae (very rare encephalitis, more frequent intracranial \\
haemorrhage) \\
\hline Rabies viruses \\
\hline
\end{tabular}

Table 14.2c Viral causes of myelitis (direct viral invasion) (Cree 2014; Roman 2014)

\begin{tabular}{l}
\hline Poliomyelitis viruses \\
\hline West Nile virus \\
\hline Tick-borne encephalitis virus \\
\hline Japanese encephalitis virus \\
\hline Chikungunya virus (mainly myelo-radiculitic form) \\
\hline Rabies viruses (dumb rabies: radiculomyelitis)
\end{tabular}

increasing qualitative and quantitative impairment of consciousness. It must be, however, noted that the clinical presentation also depends, at least to some extent, on the specific virus. Arboviruses, in particular Japanese encephalitis virus, West Nile virus and tick-borne encephalitis virus, may manifest with a predominating basal ganglia syndrome, tremor, bradykinesia and rigidity being the most important signs and symptoms. The course of the disease might evolve into a status epilepticus, a condition which carries a very high morbidity and acute mortality. In encephalitis, focal and/or generalised seizures may occur in up to $60 \%$ of the cases 
(Handique and Handique 2011; Lyons and McArthur 2013; Misra et al. 2014; Nicolasora and Kaul 2008; Ross 2014; Rudolph et al. 2014).

\subsubsection{Viral Myelitis}

A direct invasion of viruses into the myelon is rather typical for enteroviruses (Huang and Shih 2014), frequently causing a well-circumscribed myelitis within the grey matter of the myelon, i.e. a poliomyelitic course of disease. Besides enteroviruses (poliomyelitis viruses, enterovirus 69-71), West Nile viruses and tick-borne encephalitis virus may also cause a poliomyelitic course of disease. Rare cases of "poliomyelitis" have been described in Chikungunya virus and in Japanese encephalitis. Completely different - from a direct viral invasion into the myelon - is the post- or parainfectious myelitis which frequently presents as a transverse myelitis (Cree 2014; Roman 2014; Tyler 2014).

\subsubsection{Diagnostic Features}

History of exposure (mumps, measles) and the clinical syndrome of the respective infectious disease (again mumps, measles or varicella, shingles, etc.) are - in case the patients develop signs and symptoms of acute meningitis - highly suggestive of the aetiology of meningitic disease. In pure meningitis, neuroimaging neither is indicated nor carries a chance of suggestive findings. However, if the viral meningitis progresses to meningoencephalitis or meningoencephalomyelitis or if the presenting features suggest encephalitis or myelitis, neuroimaging is essential, both in ascertaining and confirming the neurological syndrome and being helpful in establishing the appropriate diagnosis and prognosis. The most important is neuroimaging - if possible, at any rate, nuclear magnetic resonance imaging - in case of meningoencephalitis, since certain patterns of affection within the brain frequently allow the best possible "guess" in attributing the disease to a certain virus family (Table 14.3).

Electroencephalography is indicated in case of encephalitic signs and symptoms, with or without epileptic features. Both epilepsy-specific EEG changes and focal or diffuse abnormalities are clearly associated with a malfunction of the cortical areas, thereby allowing to objectivise the clinical syndrome of an encephalitis. In case of myelitis, somatosensory-evoked potentials and motor-evoked potentials help to classify an incomplete poliomyelitic or transverse myelitis course of disease, both allowing early diagnosis and accompanying ascertainment of the clinical course.

Table 14.3 Virus-specific typical localisation in neuroimaging (Gupta et al. 2012)
Flaviviruses: basal ganglia, thalami

Enteroviruses: thalami

Herpes simplex type 1: fronto-temporo-basal

Rabies: brainstem, initially in particular medulla oblongata 


\subsubsection{Non-CSF Laboratory Analyses}

In viral CNS disease, the extra CSF laboratory values do not usually yield a specific result. It is essential to point towards the capacity of a wide range of viruses to involve - beside the meninges - also other organs, like the liver, kidney, etc. Therefore, minor laboratory signs of hepatic or renal involvement might easily underline the viral pathogenesis. However, only Epstein-Barr virus or cytomegalovirus clearly and regularly affect the kidney and/or liver so that the aetiological involvement of one of these viruses might correctly be surmised. Leucocyte count, $\mathrm{C}$-reactive protein or procalcitonin do not show a clear pattern in the case of viral meningitis. In contrast to this, the differential count frequently shows a relative lymphocytosis; in case of Epstein-Barr-virus or cytomegalovirus infection, monocytes predominate differential white blood cell count.

\subsubsection{Cerebrospinal Fluid (CSF)}

In many cases of viral meningitis, in the earliest hours of the disease, a mixed or even predominantly polymorphonuclear leucocytosis in the CSF might be found. However, this is rapidly followed (within 12-24 h) by a predominance of the lymphocytes and monocytes. The CSF glucose and the CSF/serum glucose ratio are normal, and in the case of viral meningitis, CSF protein is only mildly elevated and CSF lactate normal. The microbiological diagnostic studies in a patient with viral meningitis or encephalitis are shown in Table 14.4.

\subsubsection{Differential Diagnosis}

Table 14.5 lists nonviral causes of lymphocytic/aseptic meningitis syndrome, a disease which might be mistaken for a viral CNS infection.

\subsubsection{Therapeutic Management}

\subsubsection{Antiviral Therapies}

If diagnosed early enough, enteroviral meningitis can be treated with pleconaril $200 \mathrm{mg}$ t.i.d. for 1 week, herpes simplex virus type 2 meningitis with acyclovir $1,000 \mathrm{mg}$ daily for 10 days and varicella zoster virus meningitis with acyclovir $2-3 \mathrm{~g}$ daily for 5 days, and a patient with acute HIV meningitis should receive a combination therapy (2 nucleoside analogue reverse transcriptase inhibitors or a non-nucleoside reverse transcriptase inhibitor combined with 2 nucleoside analogues). Every patient with signs and symptoms of viral encephalitis receives acyclovir intravenously (10 $\mathrm{mg} / \mathrm{kg}$ b.w. t.i.d.). If the clinical course and both the neuroimaging/EEG and the CSF PCR clearly exclude HSV1 aetiology, acyclovir is stopped and either another specific treatment, if indicated, or at least symptomatic therapy is initiated. 
Table 14.4 Diagnostic studies for microbiological/serological studies

Enteroviruses including poliomyelitis

CSF viral culture CSF RT-PCR

Throat and stool culture

Arboviruses

CSF IgM antibody-capture ELISA

CSF PCR West Nile virus

Paired acute and convalescent sera ${ }^{a}$

Herpes simplex virus (HSV)

CSF PCR HSV DNA

Genital lesions

Epstein-Barr virus

Serology

Heterophilic antibodies

Antiviral capsid antigen (VCA) titres of 1:320 or higher

EBV VCA IgM antibodies

Absence of anti-EBNA IgG antibodies

CSF PCR EBV DNA

Human immunodeficiency virus (HIV)

CSF PCR HIV-1 RNA

Anti-HIV-1 IgG in CSF

CSF viral culture

Varicella zoster virus (VZV)

CSF PCR VZV DNA

CSF VZV IgG antibodies (serum/CSF ratio)

CSF VZV IgM antibodies

HHV-6

Isolation of virus in CSF culture

Plus

Paired acute and convalescent sera ${ }^{\mathrm{a}}$

Lymphocytic choriomeningitis virus

Herpes simplex virus 2

Cultures are positive for herpes simplex virus 2 in the majority of cases of meningitis associated with primary genital herpes, but they rarely are positive in recurrent episodes

Paired acute and convalescent sera mumps

Paired acute and convalescent sera ${ }^{\mathrm{a}}$

Modified according to Brouwer et al. (2013), Franzen-Rohl et al. (2008), Nigrovic (2013), Putz et al. (2013), Ross (2014)

$C S F$ cerebrospinal fluid, $P C R$ polymerase chain reaction, $R T-P C R$ reverse transcription-polymerase chain reaction

${ }^{a}$ Fourfold or greater increase in $\mathrm{IgG}$ between acute and convalescent sera 
Table 14.5 Nonviral causes of acute lymphocytic/aseptic meningitis syndrome

\begin{tabular}{l}
\hline Infectious causes \\
\hline Trypanosoma cruzi \\
\hline Cysticercus cellulosae \\
\hline Larva migrans \\
\hline Cryptococcus neoformans \\
\hline Coccidioides immitis \\
\hline Histoplasma capsulatum \\
\hline Sporothrix schenckii \\
\hline Mycobacterium tuberculosis \\
\hline Mycoplasma pneumoniae \\
\hline Rickettsia spp. \\
\hline Bartonella henselae \\
\hline Anaplasma spp. \\
\hline Treponema pallidum \\
\hline Borrelia burgdorferi \\
\hline Noninfectious causes \\
\hline Sarcoidosis \\
\hline Leptomeningeal carcinomatosis \\
\hline Lymphoma \\
\hline Wegener granulomatosis \\
\hline Behcet's disease \\
\hline Systemic lupus erythematosus \\
\hline Drugs \\
\hline Nonsteroidal anti-inflammatory agents \\
\hline Sulphonamides \\
\hline Intravenous immunoglobulins \\
\hline OKT3 antibodies \\
\hline Isoniazid \\
\hline
\end{tabular}

Table adapted according to Auriel et al. (2014), Blasi et al. (2009), Greenblatt et al. (2013), Putz et al. (2013), Ross (2014)

Patients with viral meningitis do not need specific antiviral therapy; however, the best possible symptomatic care, e.g. analgesics, anti-emetics, etc., is essential. Clinical observation supplements the acute care. Specific antivirals or the administration of hyperimmunoglobulins is not recommended in a case with pure viral meningitis (De Souza and Madhusudana 2014; Nigrovic 2013; Putz et al. 2013; Ross 2014).

\subsubsection{Symptomatic/Adjunctive Therapies}

Every patient with a potentially life-threatening course of encephalitis and/or myelitis must be managed in an (neuro) ICU. If intracranial pressure is suspected, the placement of an ICP probe is indispensable; if ICP remains elevated or cerebral perfusion pressure is dangerously low $(<50 \mathrm{mmHg})$, immediate follow-up neuroimaging is mandatory. 
Fig. 14.1 Epstein-Barr virus encephalitis with life-threatening diffuse brain oedema, successful bilateral decompressive craniectomy

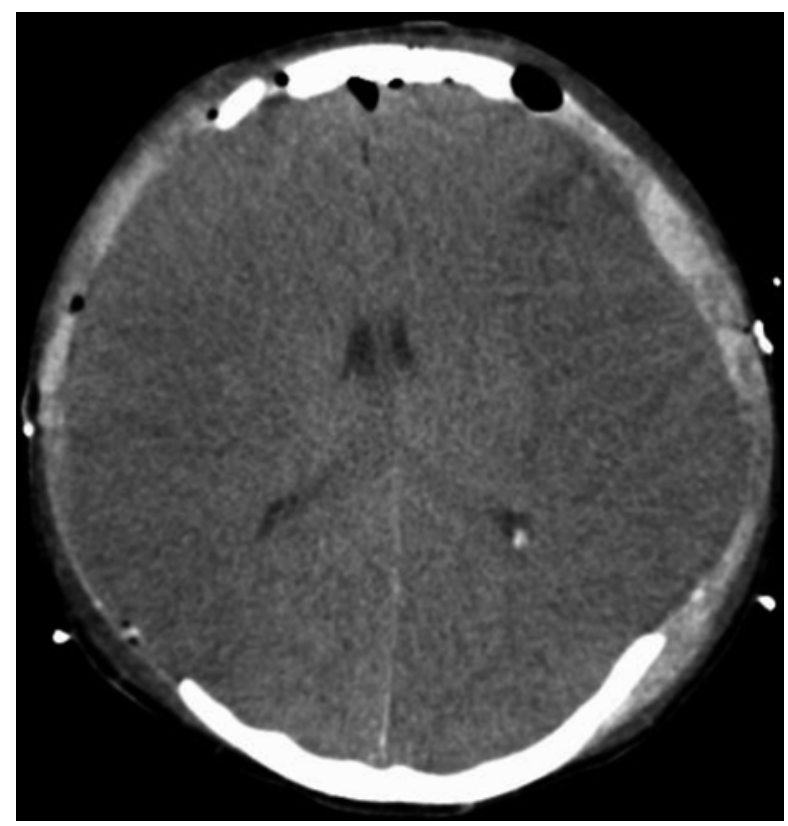

Encephalitic brain oedema may be diffuse or focal; however, anti-oedematous therapy with corticosteroids or osmotherapy is still a matter of discussion. No prospective randomised trials with respect to corticosteroids or osmotherapy exist for viral encephalitides. A small group of patients with severe viral encephalitis and hyperpyrexia may benefit from therapeutic hypothermia or, at least, therapeutic normothermia, i.e. targeted temperature management or decompressive craniectomy (Fig. 14.1).

Isolated seizures, a common finding in encephalitis, need to be treated as any other symptomatic epileptic seizure. In the case of refractory status epilepticus, barbiturates may be considered; however, this group of drugs should only be given in encephalitic patients if an ICP monitoring probe is in place and the patient is on continuous EEG monitoring (Edberg et al. 2011).

\subsubsection{Prognosis}

Short-term and long-term prognosis in a patient with pure lymphocytic, viral meningitis is good, long-term mortality virtually zero and long-term morbidity also very low. In encephalitis and encephalomyelitis, long-term morbidity and mortality is definitely much higher than in pure meningitis. Without treatment, herpes simplex virus type 1 encephalitis carries a mortality rate of $70 \%$, the European tick-borne encephalitis or myelitis carries a mortality rate of up to $10 \%$, and the far eastern variant of TBE (Russian spring summer time encephalitis) has a mortality rate 
similar to Japanese encephalitis (30\%). Patients who survive an encephalitis or a myelitis have a likelihood of $>10 \%$ to suffer from severe neurological long-term sequelae, paraplegia or tetraplegia and epilepsy as well as focal or diffuse encephalopathies being the major long-term sequelae in patients with severe encephalitis and/or myelitis (Nigrovic 2013; Putz et al. 2013; Ross 2014; Zhang et al. 2014).

\subsubsection{Prophylaxis}

The avoidance of exposure to the various pathogenic agents (by avoiding areas of increased risk of transmission) and exposure to vectors in the case of arboviruses and the avoidance of close contacts in the case of droplet-, faeco-oral route of infection (mumps, measles, enteroviruses, etc.) are the most important steps of prevention. When available, active immunisation is a highly efficacious way to avoid the respective viral CNS disease (TBE, Japanese encephalitis, measles, mumps, poliomyelitis etc.).

\subsection{Acute Bacterial Meningitis}

\subsubsection{Introduction}

Acute bacterial meningitis is one of the most important acute inflammatory diseases of the central nervous system, early diagnosis and immediate initiation of the best possible empirical therapy being extremely important in reducing morbidity and the still high mortality. Despite improvements in antimicrobial chemotherapy over the past decades, neurological sequelae and mortality still remain unacceptably high for which mainly intracranial complications are responsible. The earliest possible recognition of such intracranial complications, e.g. diffuse brain oedema, status epilepticus, meningovasculitis leading to stroke, sinus or intracranial venous thrombosis, hydrocephalus, pyocephalus, is needed to allow - equally important - the earliest possible adequate adjunctive therapeutic measures. Only very recently, neurocritical care measures, by means of invasive intracranial pressure monitoring, have been shown to lead to an improvement of mortality in comatose patients with acute bacterial meningitis (from 30 to $10 \%$ ). Therefore, the earliest possible diagnosis, earliest possible specific and adjunctive therapeutic measures as well as monitoring and management in an intensive care unit setting are, besides prevention, the essential clue to further improve morbidity and mortality in acute bacterial meningitis.

\subsubsection{Epidemiology}

Worldwide, the incidence of acute bacterial meningitis is estimated to be 5-10 cases per 100,000 persons/year. These figures have changed dramatically throughout the past decade, in particular after the introduction of Haemophilus influenzae type B 
vaccine and the growing number of persons at risk who receive the appropriate polyvalent pneumococcal vaccine. Since the immunogenicity and safety of the multicomponent recombinant meningococcal serogroup B vaccine has been shown, the European Medicines Agency (EMA) issued an approval of this vaccine in January 2013. Serogroup B meningococci being responsible for more than $60 \%$ of meningococcal diseases in central European countries, the other third mostly being caused by serogroup C meningococci (Bijlsma et al. 2014), it seems reasonable to assume that within the coming years, acute bacterial meningitis due to the "common pathogenic agents", i.e. pneumococci and meningococci, will become rare events, the incidence dropping well below 1/100,000/year, as has been seen in the 1990s in Europe or a decade later in African countries for Haemophilus influenzae type B meningitis. Due to the demographic development and the fact that the ageing population will suffer more and more from various co-morbidities, enhancing the risk of either hitherto unusual or even unknown pathogenic agents leading to bacteraemia (e.g. Gram negatives, anaerobes, etc.), it might be assumed that in the future years, both community-acquired meningitis due to unusual bacterial pathogens and nosocomial bacterial meningitis in the case of invasive therapeutic or monitoring procedures (external ventricular drain, intracranial pressure probe, other monitoring probes, more invasive neurosurgical procedures, etc.) will replace the so far common and well-known pathogenic agents, in particular pneumococci and meningococci (Bhimraj 2012; Kasanmoentalib et al. 2013; Pomar et al. 2013). In the so-called meningitis belt - Sub-Saharan Africa, Arab Peninsula and northern part of India and Pakistan - meningococci still are the cause of epidemics, incidence rates being as high as 1,000/100,000/year in such an epidemic setting. However, even in sub-Saharan Africa, a change of epidemiology has been seen, these meningococcal epidemics moving from the immediate semiarid area of the Sahel zone towards the southern countries, extending towards Angola, Mozambique or Namibia.

Specific attention has to be paid to the development of antibiotic resistance, which has been shown, in particular, to be the case for Streptococcus pneumoniae (pneumococci), becoming more and more prevalent in Asia, the USA and in certain European countries. Almost 20 years ago, already a third of cases of pneumococcal meningitides in the USA were caused by organisms not susceptible to penicillin, in European countries (Spain, France, Hungary, etc.) penicillin resistance rates even reaching more than $50 \%$. Very rare cases of penicillin resistance strains of Neisseria meningitidis (meningococci) have been reported so far. Besides this, age and seasonality and the place of acquiring the meningitis (community acquired versus nosocomial) are important epidemiological features in acute bacterial meningitis. Neonates and young children show a completely different pattern of pathogenic agents as do children and adolescents; these, again, show a different distribution of pathogenic agents compared to elderly and old patients. It is mainly age but also other predisposing factors like immunocompromised state, e.g. traumatic brain injury, preceding parameningeal infection (sinusitis, otitis, mastoiditis) which predispose patients to pneumococcal meningitis (Fig. 14.2). Neurosurgical interventions, open traumatic brain injury and invasive monitoring devices carry a high risk (up to $3 \% /$ day) for nosocomial meningitis, caused by staphylococci or Gram negatives. 
Fig. 14.2 Frontal sinusitis extending towards the meninges, causing pneumococcal meningitis with subdural empyema

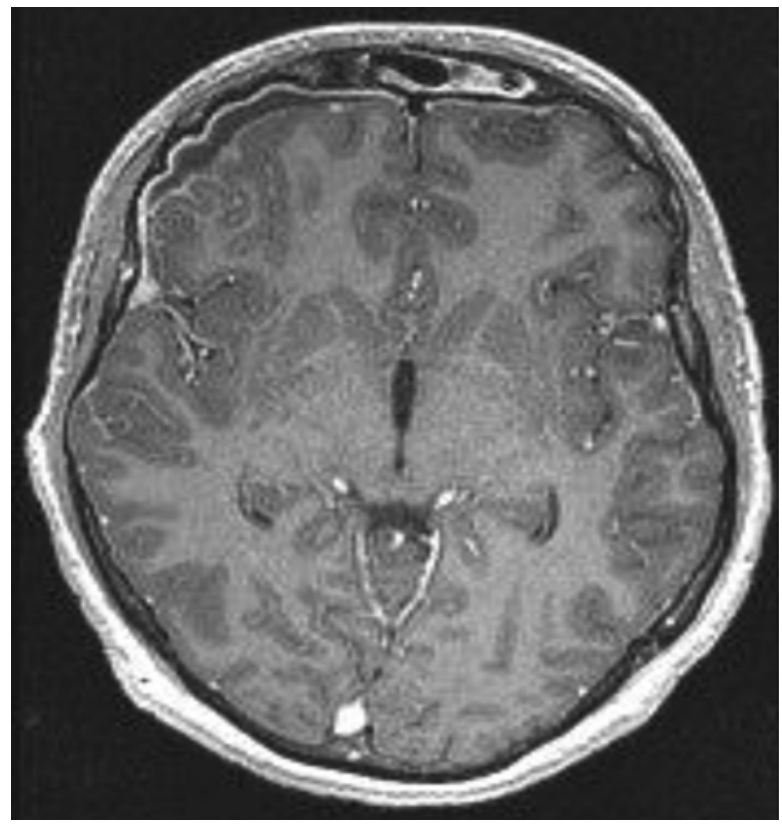

Community-acquired meningitis is usually caused by pneumococci or meningococci; in neonates, however, group B streptococci, Listeria spp. and Gram negatives are most frequently seen. In the elderly, potentially immunocompromised patients, pneumococci, Listeria spp. and Gram negatives are the major causative agents for bacterial meningitis. In nosocomial meningitis (hospital-acquired meningitis), staphylococci or streptococci other than S. pneumoniae and, in particular, Gramnegative rods (e.g. Enterobacter spp., Klebsiella spp., Escherichia coli, Pseudomonas aeruginosa or Acinetobacter spp.) are the most frequently seen pathogenic agents.

\subsubsection{Pathogenesis and Pathophysiology}

Table 14.6a lists the most common pathogens of bacterial meningitis with respect to age and Table $14.6 \mathrm{~b}$ with respect to predisposing conditions (the latter in adults) (Roos and van de Beek 2010; Sellner et al. 2010).

Any bacterial pathogen which succeeds to cross the blood-brain barrier has the potential to cause acute bacterial meningitis. This sequence of events eventually leads to bacterial meningitis: colonisation of the host mucosal epithelium, successfully overcoming the local (mucosal) immune mechanisms (e.g. with the help of viral pharyngitis, laryngitis, rhinitis), invasion (and survival) within the intravascular space, arrival at the choroid plexus with successful crossing/penetration of the blood-brain barrier and, finally, survival and multiplication within the CSF. Replication and autolysis of bacteria lead to the release of bacterial cell wall components into the CSF, which is the most powerful stimulus to provoke the release of proinflammatory host factors (Mook-Kanamori et al. 2014; Sellner et al. 2010). Experimental and clinical studies have helped specify the complex 
Table 14.6a Most common pathogens in acute bacterial meningiti

\begin{tabular}{|c|c|}
\hline Age & Most common bacteria \\
\hline \multirow[t]{3}{*}{$<1$ month } & Gram-negative Enterobacteriaceae \\
\hline & Streptococcus agalactiae (group B streptococci) \\
\hline & Listeria monocytogenes \\
\hline 1 year -12 months & $\begin{array}{l}\text { S. pneumoniae, N. meningitidis, H. influenzae type B, S. agalactiae, } \\
\text { E. coli }\end{array}$ \\
\hline 1 year -18 years & N. meningitidis, $H$. influenza type B, S. pneumoniae \\
\hline $19-50$ years & S. pneumoniae, N. meningitidis \\
\hline$>50$ years & $\begin{array}{l}\text { S. pneumoniae, Listeria monocytogenes, Enterobacteriaceae, } \\
\text { N. meningitidis }\end{array}$ \\
\hline
\end{tabular}

Table 14.6b Acute bacterial meningitis: predisposing factor

\begin{tabular}{l|l}
\hline Predisposing factor in adults & Typical pathogen \\
\hline $\begin{array}{l}\text { Healthy, immunocompetent (community } \\
\text { acquired) }\end{array}$ & $\begin{array}{l}\text { S. pneumonia, } \text {. meningitidis, } \\
\text { L. monocytogenes }\end{array}$ \\
\hline $\begin{array}{l}\text { Nosocomial (hospital acquired, post- } \\
\text { neurosurgical, posttraumatic brain injury, device } \\
\text { related (e.g. external ventricular drainage, etc.)) }\end{array}$ & $\begin{array}{l}\text { Staphylococci, Enterobacteriaceae, } \\
\text { Pseudomonas aeruginosa }\end{array}$ \\
\hline Shunt infection & $\begin{array}{l}\text { Staphylococcus epidermidis, } \\
\text { Staphylococcus aureus, Enterobacteriaceae, } \\
\text { Pseudomonas aeruginosa }\end{array}$ \\
\hline Immunosuppressed patients & $\begin{array}{l}\text { Listeria monocytogenes, } \\
\text { Enterobacteriaceae, } \text { Pseudomonas } \\
\text { aeruginosa, pneumococci }\end{array}$ \\
\hline Old/elderly patients & $\begin{array}{l}\text { Listeria monocytogenes, pneumococci, } \\
\text { Enterobacteriaceae }\end{array}$ \\
\hline
\end{tabular}

pathogenic network in bacterial meningitis. Part of this network are cytokines (interleukin $1 \beta$, interleukin 6 , tumour necrosis factor- $\alpha$ ), chemokines, reactive oxygen species and reactive nitrogen intermediates (Mook-Kanamori et al. 2014; Sellner et al. 2010). Such chemotactic factors, and induced adhesion molecules, mediate the massive influx of leucocytes into the CSF (Sellner et al. 2010). It is this complex pathogenic network which contributes to CNS complications and brain damage, as there is hydrocephalus, meningovasculitis, venous/sinus thrombosis, brain oedema and eventually increased intracranial pressure. Besides these intracranial pathophysiological processes, in many cases, life-threatening systemic signs and symptoms can be attributed to related septicaemia, septic shock and even Waterhouse-Friderichsen syndrome. Bilateral adrenal haemorrhage, as typically seen in Waterhouse-Friderichsen syndrome, is thought to be rather a terminal phenomenon than the immediate cause of a potentially fatal adrenal insufficiency. Patients with meningococcal septicaemia, with overwhelming pneumococcal sepsis syndrome (in splenectomised patients) (Adriani et al. 2013), and patients with accompanying Gram-negative sepsis syndrome are highly likely to develop multiorgan failure, including shock, coagulopathy, kidney and liver failure, myocardial failure, pericarditis, arthritis, intestinal failure and metabolic derangement including SIADH, hyperglycaemia, etc. All these aspects contribute to morbidity and mortality. 


\subsubsection{Clinical Features}

Typically, acute bacterial meningitis presents with headache, fever, photophobia, vomiting and malaise, neck stiffness and, eventually, qualitative and/or quantitative impairment of consciousness and seizures (Bhimraj 2012). In the very old and in the very young as well as the deeply comatose patient, neck stiffness may be very mild or even absent. Almost every patient ( $>95 \%)$ with acute bacterial meningitis complains at least of two of the four symptoms: headache, fever, neck stiffness and qualitative/quantitative impairment of consciousness. The potentially lifethreatening clinical signs and symptoms can evolve very rapidly within few hours, thus, rendering the disease a true neurological emergency. It is the earliest possible diagnosis with the earliest possible initiation of antimicrobial chemotherapy and the necessary initiation of adjunctive therapeutic measures that are the most important factors in reducing morbidity and mortality. Purpura fulminans (on presentation) is typical for meningococcal meningitis and sepsis syndrome but can also be seen in staphylococcal or pneumococcal disease. About $10 \%$ of meningococcal infection shows a fulminant meningococcal septicaemia (Waterhouse-Friderichsen syndrome) which is characterised by septic shock, large petechial haemorrhages, multiorgan failure and disseminated intravascular coagulation (Fig. 14.3a-d). Such petechiae need to be differentiated from Osler's spots (typically located on the fingers and toes) which are highly suggestive of infective endocarditis. In up to $15 \%$

Fig. $14.3(a-d)$

Meningococcal meningitis and meningococcal sepsis syndrome, purpura fulminans (a, b, day 3 after onset; c, d, day 19 after onset)
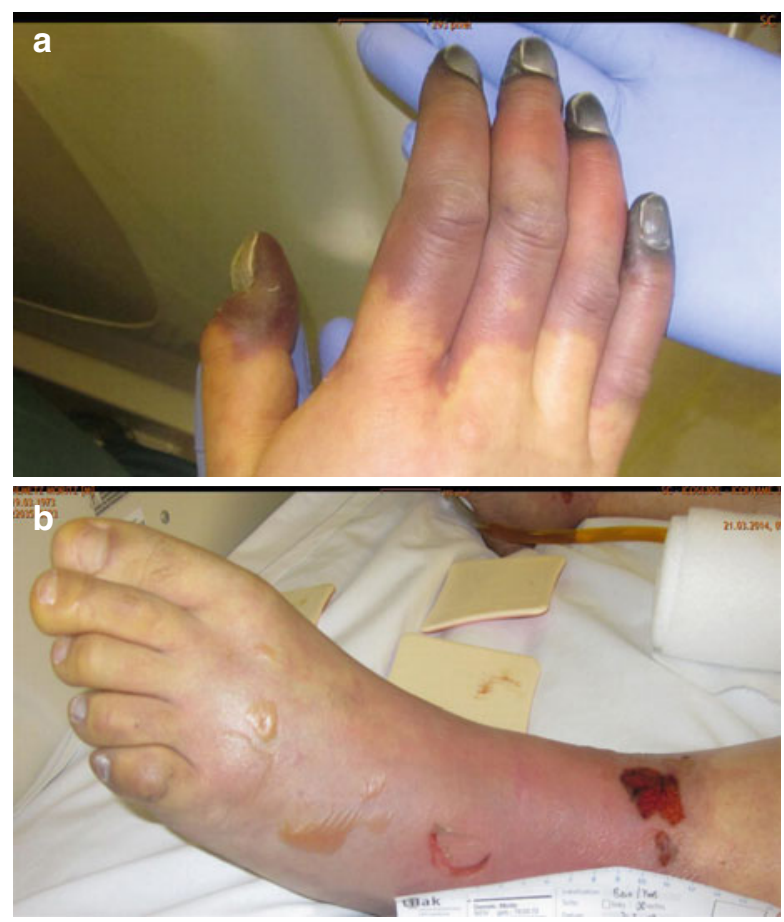
Fig. 14.3 (continued)
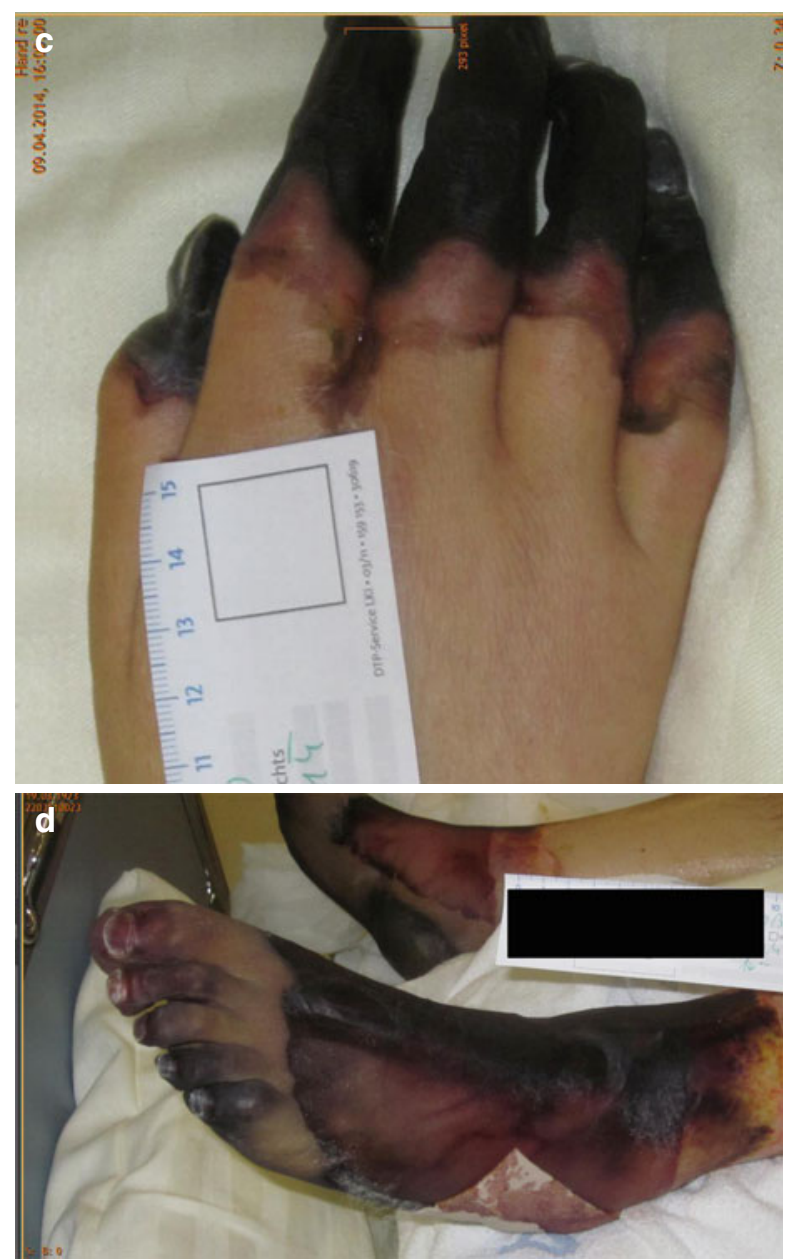

of patients with bacterial meningitis, focal neurological signs and symptoms may be found, suggesting brain abscess, subdural or epidural empyema, stroke or venous thrombosis (Alvis Miranda et al. 2013). Cranial nerve involvement is seen in approximately $10 \%$ of patients with acute bacterial meningitis; seizures occur in up to a third of these patients.

The course of meningococcal disease is frequently characterised by sepsis syndrome and septic shock, whereas the course of pneumococcal meningitis more often is characterised by intracranial complications.

Posttraumatic bacterial meningitis is often clinically indistinguishable from community-acquired meningitis. Therefore, in any traumatic brain injury patient, fever, deterioration of consciousness and impairment of vital function may indicate the advent or the presence of acute nosocomial meningitis. The presence of a CSF leak clearly supports the notion of a nosocomial meningitis which might, however, be hard to detect. 
Fig. 14.4 Patient with clinical signs and symptoms of acute bacterial meningitis and left frontal focal signs - acute bacterial meningitis + frontal abscess

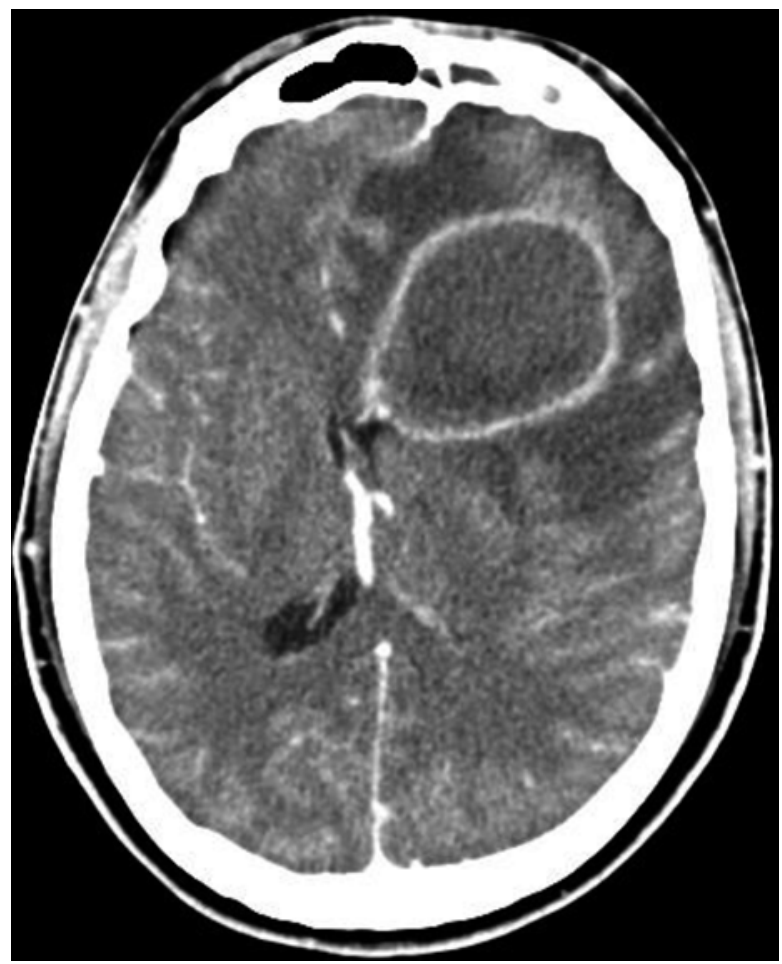

An infected permanent cerebrospinal fluid shunt usually causes a more insidious onset of disease with low-grade fever and with features typical for shunt malfunction, like headache, vomiting and impaired consciousness. Fever, usually a sign of CNS infection, is frequently absent in shunt infections. It should be noted that the peripheral part of the shunt may be infected without causing signs and symptoms of meningitis. Shunts draining into the venous system might produce a right-sided infective endocarditis; infection of shunts draining into the peritoneal cavity may produce focal or even diffuse peritonitis (Aftab and Shoaib 2013).

\subsubsection{Diagnostic Features}

The history, in particular the presence of predisposing factors or meningococcal disease in contact persons, the typical signs and symptoms of acute bacterial meningitis and/or sepsis syndrome are highly suggestive for the disease. The positive proof of the diagnosis can only be done by examining the cerebrospinal fluid. Every patient with suspected bacterial meningitis needs a spinal tap (Glimåker et al. 2013b); however, before that, neuroimaging is indicated if the patient shows impairment of consciousness and/or focal neurological signs and symptoms (Brouwer et al. 2014) (Fig. 14.4). In such a case, the administration of the first dose of the empirical antibiotic must never be delayed simply because of waiting for the 
Table 14.7 Emergency algorithm for a patient with suspected acute bacterial meningitis (Bhimraj 2012; Brouwer et al. 2012; Glimåker et al. 2013a; Heckenberg et al. 2014; Roos and van de Beek 2010)

Bacterial meningitis suspected

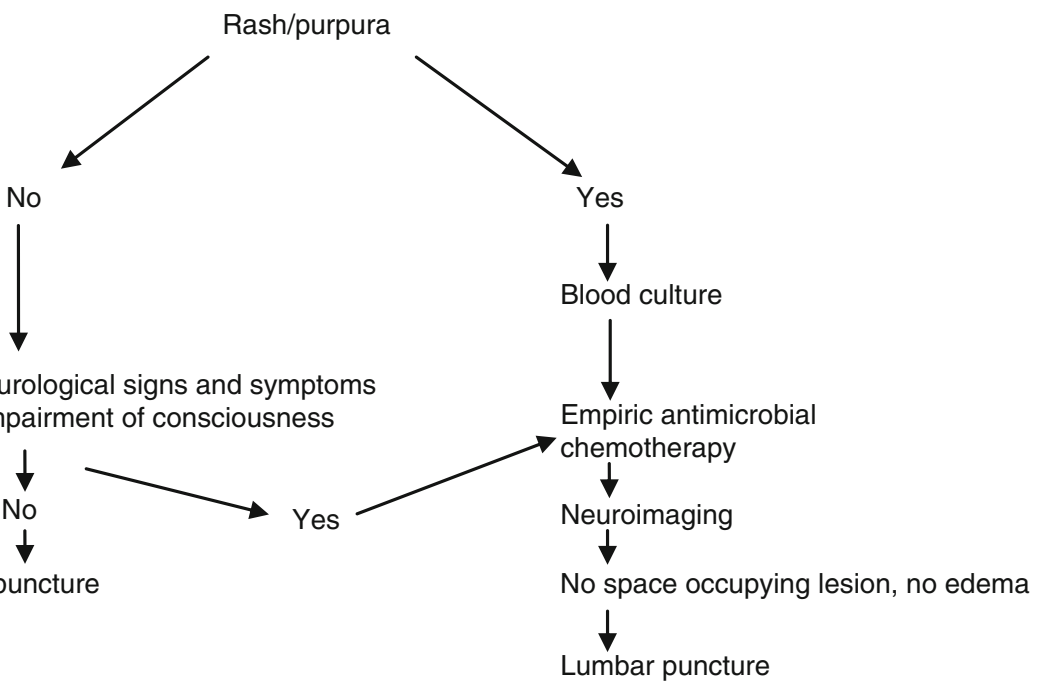

neuroimaging. The very simple algorithm shown in Table 14.7 allows the best possible emergency care management of a patient with bacterial meningitis.

\subsubsection{Non-CSF Laboratory Analyses}

In acute bacterial meningitis, septic shock is reflected by deranged laboratory parameters indicating multiple organ failure, in particular coagulation, kidney and/or liver failure. Typically, leucocyte count, C-reactive protein and, slightly later, procalcitonin are highly elevated.

\subsubsection{Cerebrospinal Fluid (CSF)}

With a pathological CSF analysis, it is important to discriminate between viral meningitis and the potentially life-threatening bacterial meningitis. The CSF in bacterial meningitis typically shows polymorphonuclear leucocytosis, decreased glucose concentration, in particular, markedly decreased CSF/serum glucose ratio, increased protein concentration and, most sensitively, increased CSF lactate. More than $90 \%$ of patients with acute bacterial meningitis show a CSF pleocytosis of more than $1,000 / \mu \mathrm{l}$ : only in the very old or immunocompromised patient the leucocyte count in the CSF might be low or even very low. With the normal CSF glucose concentration being approximately 60-70\% of the serum glucose, any CSF/serum glucose 
ratio below 0.4 is considered indicative of acute bacterial meningitis (Glimåker et al. 2013a; Hasbun et al. 2013; Heckenberg et al. 2014; Roos and van de Beek 2010; Welch and Hasbun 2010).

CSF Gram stain, CSF PCR and CSF culture are essential components for diagnosing acute bacterial meningitis. Gram staining of CSF permits a rapid identification of the pathogens with a sensitivity of up to $90 \%$ and a specificity even beyond $90 \%$. If a patient has received antibiotics prior to the lumbar puncture, CSF culture will yield a positive result in 40-50\%, whereas CSF Gram stain and CSF PCR still show a positive result in up to $90 \%$. Latex particle agglutination tests for detecting antigens of the various pathogenic agents do not increase the diagnostic yield and are no longer advised. It is in particular the PCR which has proven to add to the diagnostic accuracy, in particular if antibiotics have already been administered. Nevertheless, culture of the CSF is and will remain the golden standard for diagnosing acute bacterial meningitis, and the lumbar puncture is obligatory (in the sequence of events according to Table 14.7). Blood culture, culture from parameningeal foci and skin biopsy cultures may add to the diagnostic yield (Welch and Hasbun 2010).

\subsubsection{Differential Diagnosis}

A subacute course of tuberculous meningitis, as seen in patients on immunosuppressive therapies, fungal meningitis, fulminant meningitis due to free-living amoebae, carcinomatous meningitis, infective endocarditis with septic embolism (Fernández Guerrero et al. 2012; Ferro and Fonseca 2014) and parameningeal purulent infectious foci such as spinal/intracranial epidural abscess or subdural empyema and brain abscess need to be considered in the differential diagnostic discussion (Bijlsma et al. 2013; Brouwer et al. 2013a; Greenblatt et al. 2013). Similarly, sinus or intracranial venous thrombosis, subarachnoid haemorrhage and even severe migraine might be on the list of differential diagnoses.

\subsubsection{Therapeutic Management}

In every patient with acute bacterial meningitis, immediate diagnosis and immediate initiation of the best possible empirical antibiotic therapy are essential to reduce morbidity and mortality (Deghmane et al. 2009; Forestier 2009; Klein et al. 2009; Pines 2008; Roos and van de Beek 2010; Tessier and Scheid 2010). Table 14.8 shows the proposed algorithm, which aims to reduce both unnecessary delay of empirical antibiotic therapy and the risk of secondary damage due to herniation, brain abscess rupture etc.

It is the age which determines the likelihood of the pathogens causing bacterial meningitis, thus guiding the empirical antimicrobial therapy. Table 14.9 lists the empirical antimicrobial chemotherapy according to the age (and, hence, the most likely and most common pathogen in the respective age group). 
Table 14.8 Algorithm of therapeutic management in acute bacterial meningitis (Bhimraj 2012; Brouwer et al. 2013b; Klein et al. 2009; Pines 2008; Roos and van de Beek 2010; Tessier and Scheid 2010)

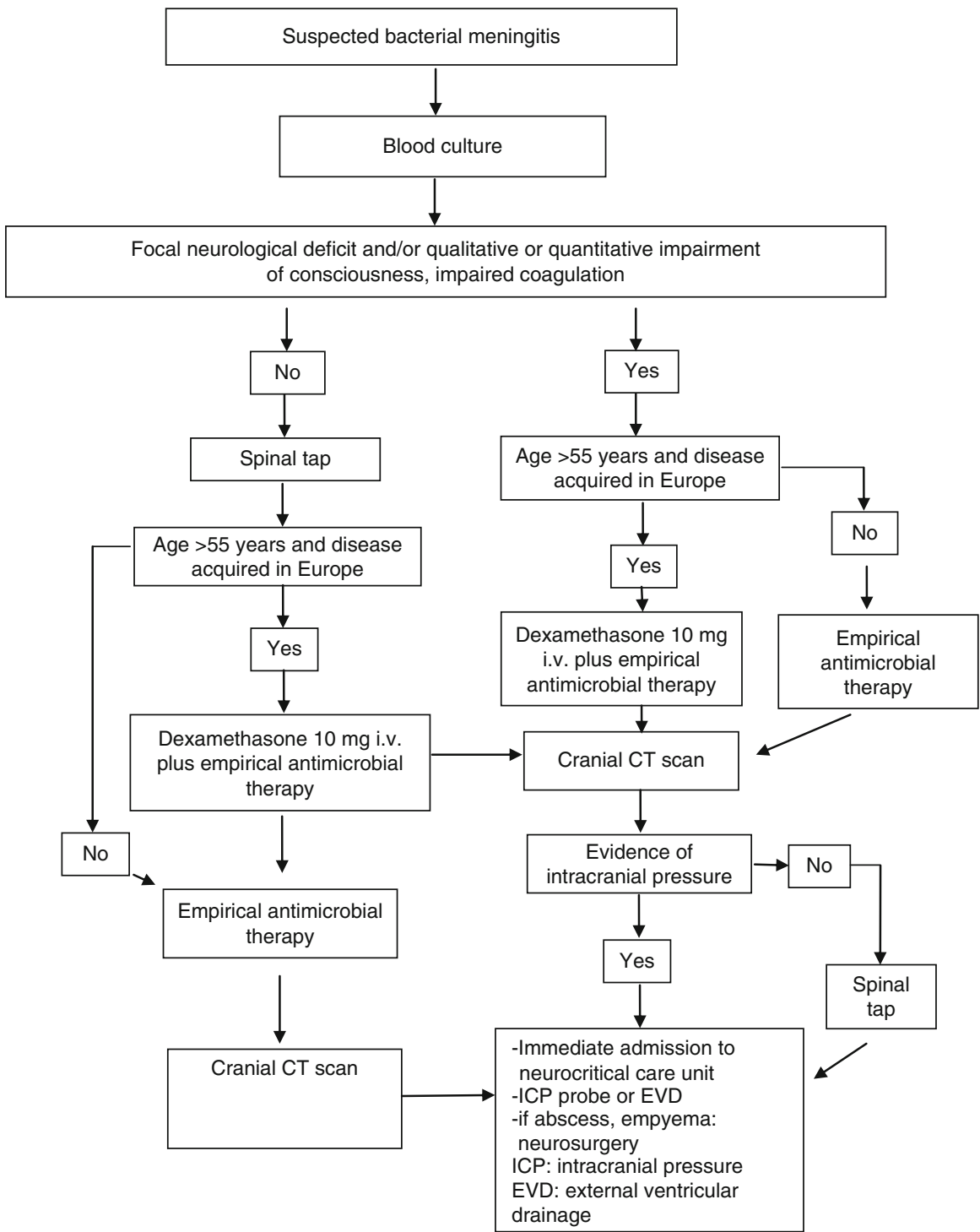

Table 14.10 lists the initial semiempirical antibiotic therapy for acute bacterial meningitis depending on the predisposing factors and the predisposing clinical condition.

If, by Gram stain PCR or culture, the pathogen finally has been determined, a de-escalation of the antimicrobial chemotherapy is recommended. Those antimicrobial chemotherapeutic agents which should be used in patients with bacterial meningitis and defined pathogen are listed in Table 14.11. 
Table 14.9 Empirical antimicrobial chemotherapy according to the age group (Bhimraj 2012; Roos and van de Beek 2010; Tessier and Scheid 2010)

\begin{tabular}{|c|c|c|}
\hline Age & Typical microorganisms & $\begin{array}{l}\text { Recommended antibiotic } \\
\text { regimen }\end{array}$ \\
\hline \multirow[t]{3}{*}{$<1$ month } & Gram-negative Enterobacteriaceae & Cefotaxime plus ampicillin \\
\hline & (E. coli, Klebsiella, Enterobacter, Proteus) & Ampicillin plus \\
\hline & S. agalactiae & Aminoglycoside \\
\hline $1-23$ months & $\begin{array}{l}\text { S. pneumoniae, } N \text {. meningitidis, } S \text {. } \\
\text { agalactiae, } H . \text { influenzae, E. coli }\end{array}$ & Ceftriaxone (plus vancomycin) \\
\hline $2-50$ years & N. meningitidis, S. pneumoniae & Ceftriaxone (plus vancomycin) \\
\hline$>50$ years & $\begin{array}{l}\text { S. pneumoniae, N. meningitidis, Listeria } \\
\text { monocytogenes, Enterobacteriaceae }\end{array}$ & $\begin{array}{l}\text { Ceftriaxone (plus vancomycin) } \\
\text { plus ampicillin }\end{array}$ \\
\hline
\end{tabular}

Table 14.10 Initial empirical antibiotic therapy for bacterial meningitis in adults (Bhimraj 2012; Roos and van de Beek 2010; Tessier and Scheid 2010)

\begin{tabular}{l|l|l}
\hline Clinical condition & Typical pathogens & $\begin{array}{l}\text { Recommended } \\
\text { antibiotics }\end{array}$ \\
\hline $\begin{array}{l}\text { Immunocompetent, community } \\
\text { acquired }\end{array}$ & $\begin{array}{l}\text { S. pneumoniae, N. meningitidis } \\
\text { L. monocytogenes }\end{array}$ & $\begin{array}{l}\text { Ceftriaxone (plus } \\
\text { vancomycin) plus } \\
\text { ampicillin }\end{array}$ \\
\hline $\begin{array}{l}\text { Nosocomial (e.g. post- } \\
\text { neurosurgical or posttraumatic } \\
\text { brain injury) ventriculitis, } \\
\text { meningitis shunt infection }\end{array}$ & $\begin{array}{l}\text { Staphylococci, Enterobacteriaceae, } \\
\text { P. aeruginosa, S. } \text { epidermidis, } \\
\text { S. aureus, Enterobacteriaceae, } \\
\text { P. aeruginosa }\end{array}$ & $\begin{array}{l}\text { Ceftazidime (or } \\
\text { meropenem) plus } \\
\text { vancomycin }\end{array}$ \\
$\begin{array}{l}\text { Immunosuppressed or older } \\
\text { patients (T-cell } \\
\text { immunodeficiency) }\end{array}$ & $\begin{array}{l}\text { L. monocytogenes, }, \\
\text { Enterobacteriaceae, } \text { P. aeruginosa, } \\
\text { pneumococci }\end{array}$ & $\begin{array}{l}\text { meropenem) plus } \\
\text { vancomycin }\end{array}$ \\
\hline
\end{tabular}

Nosocomial meningitis, ventriculo-meningitis or ventriculitis need to be treated according to the local (hospital based) resistance pattern of the most likely pathogens, e.g. Staphylococcus epidermidis, Staphylococcus aureus and Enterobacteriaceae. In such a clinical setting, either third (fourth)-generation cephalosporin or meropenem in combination with vancomycin or fosfomycin is recommended. Intraventricular vancomycin may be used for catheter (EVD)-associated ventriculitis caused by staphylococci. Linezolid has an antimicrobial efficacy similar to vancomycin or teicoplanin and shows a good blood-brain barrier penetration (Roos and van de Beek 2010; van de Beek et al. 2010).

Whether antimicrobial chemotherapy should be given as a bolus or in a continuous infusion is still a matter of discussion, most recent studies point towards the superiority of continuous administration (at least over a period of 2-4 h given by means of an injection pump) (Roos and van de Beek 2010; van de Beek et al. 2010).

The duration of antibiotic therapy is determined by the causative agent: meningococci need a minimum of 5 days, pneumococci most likely 10-14 days and 
Table 14.11 Recommended antibiotics for treatment of bacterial meningitis (Bhimraj 2012; Roos and van de Beek 2010; Tessier and Scheid 2010; Thwaites 2014)

\begin{tabular}{|c|c|c|}
\hline Causative organism & Drugs of choice & Alternatives \\
\hline N. meningitidis & Penicillin G & $\begin{array}{l}\text { Ceftriaxone (or cefotaxime), } \\
\text { ampicillin, rifampin }\end{array}$ \\
\hline $\begin{array}{l}\text { S. pneumoniae, penicillin } \\
\text { susceptible }\end{array}$ & $\begin{array}{l}\text { Penicillin G } \\
\text { (or ampicillin) }\end{array}$ & Ceftriaxone (or cefotaxime) \\
\hline $\begin{array}{l}\text { S. pneumoniae, penicillin tolerant } \\
\text { (MIC } 0,1-1 \mathrm{mg} / \mathrm{ml} \text { ) }\end{array}$ & $\begin{array}{l}\text { Ceftriaxone } \\
\text { (or cefotaxime) }\end{array}$ & Meropenem, cefepime \\
\hline $\begin{array}{l}\text { S. pneumoniae, penicillin } \\
\text { resistant (MIC } 1 \mathrm{mg} / \mathrm{ml} \text { ) }\end{array}$ & $\begin{array}{l}\text { Ceftriaxone+vancomycin } \\
\text { or ceftriaxone+rifampin }\end{array}$ & Meropenem, cefepime \\
\hline \multirow[t]{2}{*}{$\begin{array}{l}\text { H. influenzae group B } \\
\text { streptococci }\end{array}$} & $\begin{array}{l}\text { Ceftriaxone } \\
\text { (or cefotaxime) }\end{array}$ & $\begin{array}{l}\text { Ampicillin plus } \\
\text { chloramphenicol }\end{array}$ \\
\hline & $\begin{array}{l}\text { Penicillin G } \\
( \pm \text { gentamicin })\end{array}$ & $\begin{array}{l}\text { Ceftriaxone, ampicillin (plus } \\
\text { gentamicin), vancomycin }\end{array}$ \\
\hline $\begin{array}{l}\text { Gram-negative } \\
\text { Enterobacteriaceae (e.g. } \\
\text { Klebsiella, E. coli, Proteus) }\end{array}$ & $\begin{array}{l}\text { Ceftriaxone } \\
\text { (or cefotaxime) }\end{array}$ & $\begin{array}{l}\text { Meropenem, cefepime, } \\
\text { aminoglycoside }\end{array}$ \\
\hline Pseudomonas aeruginosa & $\begin{array}{l}\text { Ceftazidime } \\
( \pm \text { gentamicin })\end{array}$ & Meropenem, cefepime \\
\hline $\begin{array}{l}\text { Staphylococci (methicillin } \\
\text { susceptible) }\end{array}$ & Nafcillin & $\begin{array}{l}\text { Fosfomycin, vancomycin } \\
\text { (or flucloxacillin) }\end{array}$ \\
\hline $\begin{array}{l}\text { Staphylococci (methicillin } \\
\text { resistant) }\end{array}$ & Vancomycin & $\begin{array}{l}\text { Trimethoprim- } \\
\text { sulfamethoxazole, rifampin, } \\
\text { linezolid }\end{array}$ \\
\hline Listeria monocytogenes & $\begin{array}{l}\text { Ampicillin }( \pm \\
\text { gentamicin) }\end{array}$ & $\begin{array}{l}\text { Trimethoprim- } \\
\text { sulfamethoxazole, meropenem }\end{array}$ \\
\hline Bacteroides fragilis & Metronidazole & Meropenem, clindamycin \\
\hline
\end{tabular}

MIC minimal inhibitory concentration

Listeria spp. and Gram negatives for a minimum of 3 weeks (Roos and van de Beek 2010; Tessier and Scheid 2010; van de Beek et al. 2010).

\subsubsection{Adjunctive Therapies}

Accompanying meningovasculitis leading to stroke, diffuse brain oedema and hydrocephalus, pyocephalus, empyema and brain abscess, sinus or intracranial venous thrombosis are the most frequent intracranial complications and need to be monitored, actively looked for and managed within a neurocritical care unit (Edberg et al. 2011; Glimåker et al. 2014). Very recently, it has been shown that in case of impaired consciousness, the placement of an intracranial pressure monitoring probe and external ventricular drainage may reduce mortality from 30 to $10 \%$ (Glimåker et al. 2014). Therefore, every patient with acute bacterial meningitis and impaired consciousness needs to be monitored for intracranial pressure in a specialised neurocritical care unit. The diffuse brain oedema does not respond to osmotherapy (Ajdukiewicz et al. 2011; 
Wall et al. 2013). In the case of therapy-refractory elevated ICP (i.e. nonresponding to deepening of analgosedation, cautious hyperventilation, external ventricular drainage), second-tier management strategies need to be employed; they may include therapeutic hypothermia, barbiturate coma and even decompressive craniotomy (Mourvillier et al. 2013; Nau et al. 2013; Wall et al. 2013).

\subsubsection{Prevention}

In patients/subjects having had close (kissing mouth) contact with patients with meningococcal disease or $H$. influenzae type B meningitis, chemotherapeutic prophylactic therapy with rifampicin (600 mg p.i.d., for 2 days) or ciprofloxacin (500 mg once) is recommended.

For $H$. influenzae type B, all important serogroups of Streptococcus pneumoniae and, by now, all important serogroups of Neisseria meningitidis, active immunisation is available (Roos and van de Beek 2010).

\subsubsection{Prognosis}

By employing both the quickest possible and the best possible antimicrobial chemotherapy, the mortality rate of patients with pure acute bacterial meningitis should be below $10 \%$, even if the initial clinical situation is dangerously bad (GCS <8). However, in the case of pre-existing immunocompromised conditions (e.g. splenectomy), pneumococcal meningitis might evolve into an overwhelming pneumococcal sepsis syndrome, and in up to $50 \%$ of the patients with serogroup B or serogroup $\mathrm{C}$ meningococcal disease, the course of the disease is characterised by a sepsis syndrome with impairment of the adrenal function, coagulopathy, multiorgan failure and necrosis of the extremities, in the worst case being purpura fulminans (Waterhouse-Friderichsen syndrome), a condition which still has a very high morbidity and mortality (up to $50 \%$ ).

The most common long-term sequela in bacterial meningitis is hearing impairment. Consequences of ischaemic stroke, increased intracranial pressure and sinus thrombosis might cause diffuse or focal neurological long-term damage (including epileptic seizures) (Roos and van de Beek 2010).

\subsection{Acute Fungal Infections of the Central Nervous System}

\subsubsection{Introduction}

Over the last few decades, fungal infections of the central nervous system have been increasingly diagnosed. This is due to increased awareness, advances in neuroimaging, microbiological and molecular biological diagnostic techniques and the rapid expansion of patients being immunocompromised or immunosuppressed and may 
Table 14.12 Central nervous system in invasive fungal disease (Gullo et al. 2013; Lahoti and Berger 2013; Murthy and Sundaram 2014)

\begin{tabular}{l|l|l}
\hline Fungi & Neurological presentation & Predisposing condition \\
\hline Candida spp. & Meningitis, (micro-)abscesses & $\begin{array}{l}\text { Long-term hospitalisation, long-term } \\
\text { antibacterial chemotherapy, critical care } \\
\text { patient }\end{array}$ \\
\hline $\begin{array}{l}\text { Cryptococcus } \\
\text { neoformans } \text { spp. }\end{array}$ & $\begin{array}{l}\text { Subacute, chronic meningitis, } \\
\text { hydrocephalus, rarely } \\
\text { cryptococcoma }\end{array}$ & $\begin{array}{l}\text { HIV and other cellular-derived } \\
\text { immunocompromised state }\end{array}$ \\
\hline Aspergillus spp. & $\begin{array}{l}\text { Meningovasculitis, brain } \\
\text { abscess }\end{array}$ & $\begin{array}{l}\text { Immunocompromised state, e.g. s.p. } \\
\text { organ transplantation }\end{array}$ \\
\hline Histoplasma spp. & Meningitis, granuloma & $\begin{array}{l}\text { Geographic exposure, Latin America, } \\
\text { Southern USA }\end{array}$ \\
\hline Blastomyces spp. & Granuloma, meningitis & $\begin{array}{l}\text { Geographic exposure, HIV, Africa, } \\
\text { USA-Mississippi valley }\end{array}$ \\
\hline Zygomycetes & $\begin{array}{l}\text { Meningitis, granuloma, in } \\
\text { particular, rhinocerebral form, } \\
\text { meningovasculitis }\end{array}$ & $\begin{array}{l}\text { Immunosuppression diabetes mellitus, } \\
\text { in particular, diabetic ketoacidosis renal } \\
\text { failure, severe burns and penetrating } \\
\text { injuries }\end{array}$ \\
\hline $\begin{array}{l}\text { Coccidioides } \\
\text { immitis }\end{array}$ & $\begin{array}{l}\text { Meningitis, rarely } \\
\text { meningovasculitis }\end{array}$ & $\begin{array}{l}\text { Geographic exposure (southern USA, } \\
\text { Mexico, South America) }\end{array}$ \\
\hline
\end{tabular}

even be iatrogenically caused. It is mainly the latter condition which has led to a sharp increase in systemic fungal infection, frequently associated with central nervous system involvement. The type of central nervous system involvement is listed in Table 14.12.

\subsubsection{Epidemiology}

An immunocompromised state might be caused by HIV infection, organ transplantation, immunosuppressive chemotherapy, chronic corticosteroid therapy, malignancies in particular chemotherapy of malignant diseases, and other chronic conditions, in particular autoimmune diseases. However, several fungal pathogens may also be seen in fully immunocompetent patients, in particular Coccidioides immitis causing acute or subacute meningitis, Histoplasma spp. causing meningitis or granuloma and Cryptococcus spp. causing mainly basally accentuated meningitis. In few patients, even aspergillus granuloma or abscess formation has been seen in immunocompetent individuals (Gullo et al. 2013; Lahoti and Berger 2013; Murthy and Sundaram 2014; Pappas 2013).

\subsubsection{Aetiology and Pathogenesis}

The fungal pathogens, causing acute-subacute infection of the central nervous system, are listed in Table 14.12. Fungi are saprophytic organisms, found almost 
everywhere in soil, vegetation, skin and faeces of mammals or birds. It is usually the route via inhalation into the lung which allows entrance of fungal spoors into the body, colonising the mucosae. Secondarily, fungi spread to the lung but also haematogeneously to other organs, e.g. central nervous system. However, CNS invasion can also be by direct extension from neighbouring structures such as paranasal sinuses, pharynx or middle ear.

\subsubsection{Clinical Features}

Table 14.12 lists the most important clinical features of fungal infection: acutesubacute (also chronic) meningitis, granuloma formation, meningovasculitis and even spinal cord involvement. Of specific note is the rhinocerebral form in case of colonised paranasal sinuses by Zygomycetes. It is the focal destructive process which involves the orbit, eye, optic nerve and frontobasal brain, even involving the sinus cavernosus, eye and regional blood vessels causing blindness by central retinal artery thrombosis. Moulds, in particular, Aspergillus but also Zygomycetes, are the major cause of cerebrovascular fungal diseases causing stroke syndrome. Fungal mycotic aneurysmal subarachnoid haemorrhage is rarely seen but typically associated with very poor outcome. In rare cases spinal syndromes have been reported, either due to focal granuloma or epidural abscess or involvement of spinal arteries (Gullo et al. 2013; Lahoti and Berger 2013; Murthy and Sundaram 2014).

\subsubsection{Diagnostic Features}

It is mainly the history, the presence of predisposing factors (immunocompromised state) and geographic exposure which should draw the attention, in association with specific clinical features, towards a possible fungal aetiology (Jarvis et al. 2013; Murthy and Sundaram 2014).

\subsubsection{CSF}

Whereas in cryptococcal meningitis, a lymphocytic pleocytosis is typically found; a mixture of neutrophils and monocytes predominates in candida infection, blastomycosis, histoplasmosis and, also, Aspergillus spp. infection. However, the latter frequently shows a predominantly neutrophilic pleocytosis, which is also seen in coccidioides meningitis; this fungal pathogen, however, is frequently associated with CSF eosinophilia. Patients who are immunocompromised/immunosuppressed frequently show a very low level of pleocytosis; in the acute - subacute - course of the disease, the CSF glucose may be mildly decreased; CSF protein is definitely increased. Cryptococci can be found by India ink preparation. Cryptococcal 
antigen assays, Histoplasma antigen detection in the CSF and complement fixation antigen assays are positive in more than $80 \%$ of cases of active cryptococcal, Histoplasma or coccidioidal meningeal infection (Murthy and Sundaram 2014; Yansouni et al. 2013).

\subsubsection{Serum Antigens and Antibodies}

Serum antigen determination for Cryptococcus (Jarvis et al. 2013) or Histoplasma antigen has a specificity of more than $98 \%$, while the sensitivity is rather low in HIV-negative patients (Jarvis et al. 2013; Murthy and Sundaram 2014).

\subsubsection{Fungus-Specific Markers}

1,3-beta-d-glucan is a cell wall component of fungi and has been used as a diagnostic adjuvant in invasive fungal infections. It serves as a preliminary screening tool in the case of invasive fungal disease; however, it needs to be noted that 1,3-beta-d-glucan is always negative in infection by Zygomycetes. Other rather unspecific fungal antigens include mannan (Candida spp.), galactomannan (Aspergillus spp.) and galactoxylomannan (Cryptococcus spp.). These molecules are cell wall polysaccharides which are released by the fungi during growth. The most intriguing aspect is that these circulating molecules can be detected up to 1 week before the development of clinical signs and symptoms of systemic fungal disease. Sensitivity (for the galactomannan test) has been reported to be almost $90 \%$ with a specificity of $>98 \%$ (Murthy and Sundaram 2014; Yansouni et al. 2013).

\subsubsection{Microbiological/Mycological Diagnosis}

Fungal cultures are time consuming and laborious; for this reason, molecular biologic-based methods offer a highly specific and rather sensitive way to diagnose within a shorter time. Detection of fungal DNA by means of PCR allows a microbiologically based decision for the initiation of antifungal chemotherapy (Murthy and Sundaram 2014).

\subsubsection{Neuroimaging, Histology}

Neuroimaging will confirm the clinically suspected neurological features as there are basal meningitis, meningovasculitis, hydrocephalus and, in particular, granuloma formation. It is mainly the latter which will guide the decision to do biopsy, thereby allowing best possible confirmation diagnosis. 
Table 14.13 Therapy in CNS mycoses (Jarvis et al. 2013; Katchanov et al. 2014; Murthy and Sundaram 2014)

\begin{tabular}{l|l}
\hline Fungal pathogen & Antifungal agent \\
\hline Aspergillus spp. & $\begin{array}{l}\text { Amphotericin B (liposomal amphotericin B), voriconazole, } \\
\text { posaconazole, Caspofungin }\end{array}$ \\
\hline Candida spp. & $\begin{array}{l}\text { Amphotericin B, fluconazole, voriconazole, caspofungin, anidulafungin, } \\
\text { flucytosine }\end{array}$ \\
\hline Cryptococcus spp. & Combination therapy: amphotericin B and 5-flucytocine; fluconazole \\
\hline Coccidioides spp. & Liposomal amphotericin \\
\hline Blastomyces spp. & Liposomal amphotericin, ketoconazole (non-immunocompromised) \\
\hline Histoplasma spp. & $\begin{array}{l}\text { Liposomal amphotericin, amphotericin B lipid complex, ketoconazole } \\
\text { (non-immunocompromised) }\end{array}$ \\
\hline Zygomycetes & Liposomal amphotericin, amphotericin B lipid complex \\
\hline
\end{tabular}

\subsubsection{Therapy}

Both the earliest possible initiation of antifungal therapy and the earliest possible reversal of the underlying host immunodeficiency are the cornerstones of treatment of CNS fungal infection. However, inflammatory responses triggered off by rapid improvement of the immune status can lead to localised and systemic reactions which are termed immune reconstitution inflammatory syndrome (IRIS), transitorily aggravating and deteriorating the neurological signs and symptoms.

Table 14.13 lists those antifungal agents which should be used if the specific diagnosis of CNS mycosis has been confirmed.

In rhinocerebral zygomycosis, neuroimaging is essential. Besides antifungal therapy, aggressive surgical debridement of necrotic tissue is required.

\subsubsection{Prognosis}

Prognosis depends on the underlying immunocompromised condition, earliest possible diagnosis, initiation of therapy and earliest possible recognition of immune reconstitution syndrome.

\subsection{Protozoal Infection and Infestation of the Nervous System}

\subsubsection{Introduction}

Protozoa and metazoa (mainly helminths) can directly or indirectly cause severe impairment of central nervous system function (Abdel Razek et al. 2011; Kristensson et al. 2013). Amoebae, Toxoplasma gondii and Trypanosoma spp. may readily invade the central nervous system causing abscess formation, acute meningoencephalitis, granuloma formation or chronic encephalitis, whereas Babesia spp. and Plasmodium 
Table 14.14 Protozoal infections of the CNS (Abdel Razek et al. 2011; Schmutzhard and Helbok 2014)

\begin{tabular}{|c|c|c|}
\hline Pathogenic agent & $\begin{array}{l}\text { Pathogenetic mechanism, } \\
\text { neurological syndrome }\end{array}$ & Geographic distribution \\
\hline Free-living amoebae & $\begin{array}{l}\text { Granuloma, fulminant } \\
\text { meningitis }\end{array}$ & Temperate climate zones \\
\hline Babesia divergens & $\begin{array}{l}\text { Anaemia-hypoxic } \\
\text { encephalopathy }\end{array}$ & $\begin{array}{l}\text { Only in splenectomised, } \\
\text { USA, Europe }\end{array}$ \\
\hline Entamoeba histolytica & Brain abscess & Tropical/subtropical areas \\
\hline Plasmodium falciparum & $\begin{array}{l}\text { Cerebral malaria (impairment } \\
\text { of microcirculation) }\end{array}$ & $\begin{array}{l}\text { Tropical regions, mainly } \\
\text { Sub-Saharan Africa, Papua } \\
\text { New Guinea, Solomon } \\
\text { Islands }\end{array}$ \\
\hline Toxoplasma gondii & $\begin{array}{l}\text { Granuloma, encephalitis } \\
\text { (immunocompromised } \\
\text { state - HIV) }\end{array}$ & Worldwide \\
\hline $\begin{array}{l}\text { Trypanosoma brucei } \\
\text { rhodesiense/gambiense }\end{array}$ & Subacute/chronic encephalitis & Tropical Africa \\
\hline Trypanosoma cruzi & $\begin{array}{l}\text { Subacute meningitis and } \\
\text { myocarditis }\end{array}$ & Latin America \\
\hline
\end{tabular}

falciparum cause potentially life-threatening CNS disease via indirect affection of the brain (Aird et al. 2014; Hawkes et al. 2013; Ho 2014; Ioannidis et al. 2014).

\subsubsection{Epidemiology}

Table 14.14 lists the protozoa which have the capacity to cause neurologic disease, the neurological syndrome, the pathogenetic mechanisms and the geographic distribution.

\subsubsection{Clinical Features}

It is mainly the history, in particular the history of exposure, as well as the predisposing underlying condition (HIV, etc.) which directs the differential diagnostic consideration towards protozoal disease. Babesiosis and, in particular, the much more frequent cerebral malaria show normal CSF; diagnosis is made in such patients by means of blood film examination showing intraerythrocytic ring forms in Giemsa stain. Cerebral malaria with multiorgan failure due to Plasmodium falciparum infection is a further typical hallmark of this life-threatening disease (Ho 2014; Ioannidis et al. 2014; Masocha and Kristensson 2012; Pittella 2013; Sondgeroth et al. 2013). Entamoeba histolytica brain abscess is only seen in patients suffering from concomitant liver abscess. Free-living amoeba (in particular Naegleria fowleri), occurring worldwide, invades the human host through the mouth/nasal mucosa via the olfactory route (when water enters the nostrils or the mouth) and causes a fulminant purulent 
meningitis, rapidly progressing to coma and death. It is the acute purulent, bacterial meningitis which is the major differential diagnosis. Therefore, such a fulminant frequently fatal disease is to be suspected when the patient reports a history of exposure to fresh water (jumping into swimming pools, etc.) in summertime.

Subacute meningitis due to Trypanosoma cruzi infection is to be suspected after exposure to the transmitting vector (reduviid bugs) in Latin America. Frequently, this meningitis is associated with myocarditis. Very rarely, Trypanosoma brucei rhodesiense presents as subacute encephalitis; typically, the course of the disease in sleeping sickness is chronic, i.e. over weeks and months.

\subsubsection{Diagnostic Features}

It is mainly the history which draws the attention towards this type of diseases. Detailed consultation of a tropical medical specialist is advised. Depending on the type of the disease, neuroimaging (Jayakumar et al. 2013), microbiological and molecular biological techniques are indicated. CSF examination shows an extremely broad variety of changes, ranging from a mild IgM increase and mild pleocytosis in sleeping sickness towards a purulent CSF with thousands of polymorphonuclear neutrophils per $\mu \mathrm{l}$, high CSF protein and low CSF glucose (in purulent meningitis due to free-living amoebae) or having virtually normal CSF as seen in Toxoplasma gondii, cerebral malaria or infection by Babesia spp.

\subsubsection{Therapy}

In those protozoal diseases which show an acute or even peracute course of disease, the earliest possible diagnosis and the quickest possible initiation of specific antiprotozoal therapy are essential. In patients with purulent meningitis due to freeliving amoebae (Naegleria fowleri), immediate initiation of amphotericin B combined with intravenous miconazole or - alternatively - amphotericin B combined with rifampicin is absolutely essential. Miconazole, however, should never be combined with rifampicin. A similarly dramatic course of disease may be seen in cerebral malaria; in such a suspected patient, immediate initiation of intravenous artesunate (if not available, intravenous quinine) is the cornerstone of therapy. Adjunctive therapeutic measures include ICU management and recognition and therapy of complications (e.g. hydrocephalus, brain oedema, etc.).

\subsection{Helminthic Infections and Infestations of the Central Nervous System}

\subsubsection{Introduction and Epidemiology}

Helminths and arthropods are metazoa which can have the capacity to penetrate the blood-brain barrier, thus invading intracranial structures. 
Table 14.15 Larvae migrantes of the CNS (Finsterer and Auer 2013; Schmutzhard and Helbok 2014)

\begin{tabular}{l|l|l}
\hline Species & Geographic distribution & $\begin{array}{l}\text { Neurological } \\
\text { features }\end{array}$ \\
\hline $\begin{array}{l}\text { Angiostrongylus } \\
\text { cantonensis and } \\
\text { Angiostrongylus } \\
\text { costaricensis }\end{array}$ & Meningitis, cranial nerve involvement & $\begin{array}{l}\text { East Asia, Central } \\
\text { America }\end{array}$ \\
\hline $\begin{array}{l}\text { Gnathostoma spinigerum } \\
\text { Strongyloides stercoralis }\end{array}$ & $\begin{array}{l}\text { Meninges, spinal cord, nerve roots, brain } \\
\text { hyperinfection syndrome accompanied } \\
\text { with purulent Gram-negative meningitis } \\
\text { and sepsis syndrome }\end{array}$ & $\begin{array}{l}\text { South East Asia, in } \\
\text { rare cases in } \\
\text { Eastern Africa }\end{array}$ \\
\hline $\begin{array}{l}\text { Toxocara canis } \text { and } \\
\text { Toxocara cati }\end{array}$ & $\begin{array}{l}\text { Rarely focal neurological signs and } \\
\text { symptoms, vasculitis, typically ocular } \\
\text { larva migrans }\end{array}$ & Worldwide \\
\hline Trichinella spp. & Myositis, rarely encephalitis & Worldwide \\
\hline
\end{tabular}

Most helminthoses of the central nervous system cause a subacute or chronic disease. They may invade in various stages of development into the brain or spinal cord causing focal or generalised neurological signs and symptoms. Echinococcus spp., Paragonimus spp., Schistosoma spp. and Cysticercus cellulosae may cause space-occupying lesions, eventually leading to increased intracranial pressure, epileptic seizures or focal and diffuse encephalopathy (Abdel Razek et al. 2011; Chai 2013; Coyle 2013; Del Brutto 2014; Finsterer and Auer 2013; McConkey et al. 2013; Nicoletti 2013; Petri and Hague 2013; Postels and Birbeck 2013; Rodgers 2010; Schmutzhard and Helbok 2014; Singh et al. 2013; Sondgeroth et al. 2013; Tudisco et al. 2013).

\subsubsection{Clinical Features}

The infestation with larvae of certain nematodes, as Angiostrongylus spp., Gnathostoma spinigerum, Strongyloides stercoralis, Trichinella spiralis and Toxocara spp., usually causes a syndrome called larva migrans visceralis. On their route through the body of the host, they may invade the central nervous system causing an eosinophilic meningitis, radiculitis, cranial nerve neuritis, myelitis and even encephalitis and, in rare cases, subarachnoid haemorrhage. The hallmark of these diseases is a high-grade eosinophilia in the peripheral blood and the CSF. In rare cases, haemorrhage in the CSF may be seen (mainly in Gnathostoma spinigerum infestation). Table 14.15 lists those nematodes which are frequently seen as the cause of eosinophilic CNS infection, their geographic distribution and the typical neurological involvement

The fish tapeworm, Diphyllobothrium latum, may cause a subacute syndrome of folic acid deficiency, thereby leading to the neurological syndrome of myelopathy, 
neuropathy and even encephalopathy. Diphyllobothrium latum has been reported from Europe, East Asia and Latin America and is acquired by ingestion of raw freshwater fish (Schmutzhard and Helbok 2014).

\subsubsection{Diagnostic Features}

The direct visualisation of the causative pathogen (e.g. migrating larva) confirms the diagnosis (Tudisco et al. 2013); in the case of eosinophilic meningitis or meningoradiculitis, the history (geographic exposure ingestion of suspected food) guides the differential diagnosis. Serological examination might be helpful to confirm the diagnosis (Rodriguez et al. 2012; Schmutzhard and Helbok 2014; Singh et al. 2013). Neuroimaging may also aid in the diagnosis (Abdel Razek et al. 2011; Lerner et al. 2012; MacLean et al. 2013; McConkey et al. 2013; Petri and Hague 2013; Pittella 2013).

\subsubsection{Therapy}

Although for those worms/larvae causing acute CNS disease the best possible anthelmintic therapy has not been evaluated in prospective and randomised studies, azole therapies (in particular albendazole) have been used and have been shown to reduce clinical signs and symptoms and the duration of the disease and to lower the frequency of long-term sequelae.

\section{References}

Abdel Razek AA, Watcharakorn A, Castillo M (2011) Parasitic diseases of the central nervous system. Neuroimaging Clin N Am 21:815-841

Adriani KS, Brouwer MC, van der Ende A, van de Beek D (2013) Bacterial meningitis in adults after splenectomy. Mayo Clin Proc 88:571-578

Aftab K, Shoaib M (2013) Nosocomial bacterial meningitis - prevention rather than cure! J Pak Med Assoc 63(7):945

Aird WC, Mosnier LO, Fairhurst RM (2014) Plasmodium falciparum picks (on) EPCR. Blood 123:163-167

Ajdukiewicz KM, Cartwright KE, Scarborough M, Mwambene JB, Goodson P, Molyneux ME et al (2011) Glycerol adjuvant therapy in adults with bacterial meningitis in a high HIV seroprevalence setting in Malawi: a double-blind, randomised controlled trial. Lancet Infect Dis 11:293-300

Alvis Miranda H, Castellar-Leones SM, Elzain MA, Moscote-Salazar LR (2013) Brain abscess: current management. J Neurosci Rural Pract 4:67-81

Auriel E, Regev K, Korczyn AD (2014) Nonsteroidal anti-inflammatory drugs exposure and the central nervous system. Handb Clin Neurol 119:577-584

Bhimraj A (2012) Acute community-acquired bacterial meningitis in adults: an evidence-based review. Cleve Clin J Med 79:393-400

Bijlsma MW, Brouwer MC, van de Beek D (2013) Prognostic risk score for pleocytosis with a negative gram stain: valid but of limited utility in bacterial meningitis patients. Mayo Clin Proc $88: 421$ 
Bijlsma MW, Brouwer MC, van den Kerkhof H, Knol MJ, van de Beek D, van der Ende A (2014) No evidence of clusters of serogroup C meningococcal disease in the Dutch MSM community. J Infect 68:296-297

Blasi F, Tarsia P, Aliberti S (2009) Chlamydophila pneumoniae. Clin Microbiol Infect 15(1):29-35

Brouwer MC, Thwaites GE, Tunkel AR, van de Beek D (2012) Dilemmas in the diagnosis of acute community-acquired bacterial meningitis. Lancet 380:1684-1692

Brouwer MC, Jim KK, Benschop KS, Benschop KS, Wolthers KC, van der Ende A, de Jong MD, van de Beek D (2013a) No evidence of viral coinfection in cerebrospinal fluid from patients with community-acquired bacterial meningitis. J Infect Dis 208(1):182-184

Brouwer MC, McIntyre P, Prasad K, van de Beek D (2013) Corticosteroids for acute bacterial meningitis. Cochrane Database Syst Rev 6:CD004405

Brouwer MC, Coutinho JM, van de Beek D (2014) Clinical characteristics and outcome of brain abscess: systematic review and meta-analysis. Neurology 4(82):806-813

Chai JY (2013) Paragonimiasis. Handb Clin Neurol 114:283-296

Coyle CM (2013) Schistosomiasis of the nervous system. Handb Clin Neurol 114:271-281

Cree BA (2014) Acute inflammatory myelopathies. Handb Clin Neurol 122:613-667

De Souza A, Madhusudana SN (2014) Survival from rabies encephalitis. J Neurol Sci 339:8-14

Deghmane AE, Alonso JM, Taha MK (2009) Emerging drugs for acute bacterial meningitis. Expert Opin Emerg Drugs 14:381-393

Del Brutto OH (2014) Neurocysticercosis. Handb Clin Neurol 121:1445-1459

Edberg M, Furebring M, Sjölin J, Enblad P (2011) Neurointensive care of patients with severe community-acquired meningitis. Acta Anaesthesiol Scand 55:732-739

Fernández Guerrero ML, Álvarez B, Manzarbeitia F, Renedo G (2012) Infective endocarditis at autopsy: a review of pathologic manifestations and clinical correlates. Medicine (Baltimore) 91:152-164

Ferro JM, Fonseca AC (2014) Infective endocarditis. Handb Clin Neurol 119:75-79

Finsterer J, Auer H (2013) Parasitoses of the human central nervous system. J Helminthol 87:257-270

Forestier E (2009) Managing adult patients with acute community-acquired meningitis presumed of bacterial origin. Med Mal Infect 39:606-614

Franzen-Rohl E, Larsson K, Skoog E, Tiveljung-Lindell A, Grillner L, Aurelius E et al (2008) High diagnostic yield by CSF-PCR for entero- and herpes simplex viruses and TBEV serology in adults with acute aseptic meningitis in Stockholm. Scand J Infect Dis 40:914-921

Glimåker M, Johansson B, Bell M, Ericsson M, Bläckberg J, Brink M et al (2013a) Early lumbar puncture in adult bacterial meningitis - rationale for revised guidelines. Scand J Infect Dis 45:657-663

Glimåker M, Lindquist L, Sjölin J, Working Party of the Swedish Infectious Disease Society for Bacterial CNS Infections (2013b) Lumbar puncture in adult bacterial meningitis: time to reconsider guidelines? BMJ 346:f361

Glimåker M, Johansson B, Halldorsdottir H, Wanecek M, Elmi-Terander A, Ghatan PH et al (2014) Neuro-intensive treatment targeting intracranial hypertension improves outcome in severe bacterial meningitis: an intervention-control study. PLoS One 9(3):e91976

Greenblatt D, Krupp LB, Belman AL (2013) Parainfectious meningo-encephalo-radiculo-myelitis (cat scratch disease, Lyme borreliosis, brucellosis, botulism, legionellosis, pertussis, mycoplasma). Handb Clin Neurol 112:1195-1207

Gullo FP, Rossi SA, Sardi Jde C, Teodoro VL, Mendes-Giannini MJ, Fusco-Almeida AM (2013) Cryptococcosis: epidemiology, fungal resistance, and new alternatives for treatment. Eur J Clin Microbiol Infect Dis 32:1377-1391

Gupta RK, Soni N, Kumar S, Khandelwal N (2012) Imaging of central nervous system viral diseases. J Magn Reson Imaging 35:477-491

Handique SK, Handique SK (2011) Viral infections of the central nervous system. Neuroimaging Clin N Am 21:777-794

Hasbun R, Bijlsma M, Brouwer MC, Khoury N, Hadi CM, van der Ende A et al (2013) Risk score for identifying adults with CSF pleocytosis and negative CSF Gram stain at low risk for an urgent treatable cause. J Infect 67:102-110 
Hawkes M, Elphinstone RE, Conroy AL, Kain KC (2013) Contrasting pediatric and adult cerebral malaria: the role of the endothelial barrier. Virulence 4:543-555

Heckenberg SG, Brouwer MC, van de Beek D (2014) Bacterial meningitis. Handb Clin Neurol 121:1361-1375

Ho M (2014) EPCR: holy grail of malaria cytoadhesion? Blood 123:157-159

Huang PN, Shih SR (2014) Update on enterovirus 71 infection. Curr Opin Virol 5C:98-104

Ioannidis LJ, Nie CQ, Hansen DS (2014) The role of chemokines in severe malaria: more than meets the eye. Parasitology 141(5):602-613

Jarvis JN, Harrison TS, Lawn SD, Meintjes G, Wood R, Cleary S (2013) Cost effectiveness of cryptococcal antigen screening as a strategy to prevent HIV-associated cryptococcal meningitis in South Africa. PLoS One 8(7):e69288

Jayakumar PN, Chandrashekar HS, Ellika S (2013) Imaging of parasitic infections of the central nervous system. Handb Clin Neurol 114:37-64

Kant Upadhyay R (2013) Biomarkers in Japanese encephalitis: a review. Biomed Res Int 2013:591290

Kasanmoentalib ES, Brouwer MC, van de Beek D (2013) Update on bacterial meningitis: epidemiology, trials and genetic association studies. Curr Opin Neurol 26:282-288

Katchanov J, Kleist MV, Arastéh K, Stocker H (2014) Time-to-amphotericin B' in cryptococcal meningitis in a European low-prevalence setting: analysis of diagnostic delays. QJM 107: 799-803

Klein M, Pfister HW, Leib SL, Koedel U (2009) Therapy of community-acquired acute bacterial meningitis: the clock is running. Expert Opin Pharmacother 10(16):2609-2623

Kristensson K, Masocha W, Bentivoglio M (2013) Mechanisms of CNS invasion and damage by parasites. Handb Clin Neurol 114:11-22

Lahoti S, Berger JR (2013) Iatrogenic fungal infections of central nervous system. Curr Neurol Neurosci Rep 13(11):399

Lerner A, Shiroiski MS, Zee CS, Law M, Go JL (2012) Imaging of neurocysticercosis. Neuroimaging Clin N Am 22(4):659-676

Lyons J, McArthur J (2013) Emerging infections of the central nervous system. Curr Infect Dis Rep 15(6):576-582

MacLean L, Myburgh E, Rodgers J, Price HP (2013) Imaging African trypanosomes. Parasite Immunol 35(9-10):283-284

Mann BR, McMullen AR, Swetnam DM, Barrett AD (2013) Molecular epidemiology and evolution of West Nile virus in North America. Int J Environ Res Public Health 10(10):5111-5129

Masocha W, Kristensson K (2012) Passage of parasites across the blood-brain barrier. Virulence 3(2):202-212

McConkey GA, Martin HL, Bristow GC, Webster JP (2013) Toxoplasma gondii infection and behavior - location, location, location? J Exp Biol 216(1):113-119

Misra UK, Kalita J, Bhoi SK (2014) Spectrum and outcome predictors of central nervous system infections in a neurological critical care unit in India: a retrospective review. Trans R Soc Trop Med Hyg 108(3):141-146

Mook-Kanamori BB, Brouwer MC, Geldhoff M, Ende AV, van de Beek D (2014) Cerebrospinal fluid complement activation in patients with pneumococcal and meningococcal meningitis. J Infect 68:542-547

Moritani T, Capizzano A, Kirby P, Policeni B (2014) Viral infections and white matter lesions. Radiol Clin North Am 52(2):355-382

Mourvillier B, Tubach F, van de Beek D, Garot D, Pichon N, Georges H et al (2013) Induced hypothermia in several bacterial meningitis: a randomized clinical trial. JAMA 310(20): 2174-2183

Murthy JM, Sundaram C (2014) Fungal infections of the central nervous system. Handb Clin Neurol 121:1383-1401

Nau R, Djukic M, Spreer A, Eiffert H (2013) Bacterial meningitis: new therapeutic approaches. Expert Rev Anti Infect Ther 11(10):1079-1095 
Nicolasora N, Kaul DR (2008) Infectious disease emergencies. Med Clin North Am 92(2): 427-441

Nicoletti A (2013) Toxocariasis. Handb Clin Neurol 114:217-228

Nigrovic LE (2013) Aseptic meningitis. Handb Clin Neurol 112:1153-1156

Pappas PG (2013) Lessons learned in the multistate fungal infection outbreak in the United States. Curr Opin Infect Dis 26(6):545-550

Petri WA, Hague R (2013) Entamoeba histolytica brain abscess. Handb Clin Neurol 114: $147-152$

Pines JM (2008) Timing of antibiotics for acute, severe infections. Emerg Med Clin North Am 26(2):245-257

Pittella JE (2013) Pathology of CNS parasitic infections. Handb Clin Neurol 114:65-88

Pomar V, Benito N, Lopoez-Contreras J, Coll P, Gurgui M, Domingo P (2013) Spontaneous gramnegative bacillary meningitis in adult patients: characteristics and outcome. BMC Infect Dis $13: 451$

Postels DG, Birbeck GL (2013) Cerebral malaria. Handb Clin Neurol 114:91-102

Putz K, Havani K, Zar FA (2013) Meningitis. Prim Care 40(3):707-726

Rodgers J (2010) Trypanosomiasis and the brain. Parasitology 137(14):1995-2006

Rodriguez S, Wilkins P, Domy P (2012) Immunological and molecular diagnosis of cysticercosis. Pathog Glob Health 106(5):286-298

Roman GC (2014) Tropical myelopathies. Handb Clin Neurol 121:1521-1548

Roos KL, van de Beek D (2010) Bacterial meningitis. Handb Clin Neurol 96:51-63

Ross KL (2014) Encephalitis. Handb Clin Neurol 121:1377-1381

Rudolph KE, Lessler J, Moloney RM, Kimush B, Cummings DA (2014) Incubation periods of mosquito-Borne Viral Infections: a systematic review. Am J Trop Med Hyg 90:882-891

Schmutzhard E, Helbok R (2014) Rickettsiae, protozoa, and opisthokonta/metazoa. Handb Clin Neurol 121:1403-1443

Sellner J, Täuber MG, Leib SL (2010) Pathogenesis and pathophysiology of bacterial CNS infections. Handb Clin Neurol 96:1-16

Singh G, Burneo JG, Sander JW (2013) From seizures to epilepsy and its substrates: neurocysticercosis. Epilepsia 54(5):783-792

Sondgeroth KS, McElwain TF, Allen AJ, Chen AV, Lau AO (2013) Loss of neurovirulence is associated with reduction of cerebral capillary sequestration during acute Babesia bovis infection. Parasit Vectors 18(6):181

Tessier JM, Scheid WM (2010) Principles of antimicrobial therapy. Handb Clin Neurol 96:17-29

Thwaites GE (2014) Brain infections in 2013: good drugs and bad bugs. Lancet Neurol 13(1): $20-21$

Tudisco JB, Fumeaux C, Petignat PA (2013) Eosinophilic meningitis, a very rare entity in Europe. Rev Med Suisse 9(406):2082, 2084-2087

Tyler KL (2014) Current developments in understanding of West Nile virus central nervous system disease. Curr Opin Neurol 27(3):342-348

van de Beek D, Drake JM, Tunkel AR (2010) Nosocomial bacterial meningitis. N Engl J Med 362(2):146-154

Wall EC, Ajdukiewicz KM, Heyderman RS, Garner P (2013) Osmotic therapies added to antibodies for acute bacterial meningitis. Cochrane Database Syst Rev 3:CD008806

Welch H, Hasbun R (2010) Lumbar puncture and cerebrospinal fluid analysis. Handb Clin Neurol 96:31-49

Yansouni CP, Bottieau E, Lutumba P, Winkler AS, Lynen L, Büscher P (2013) Rapid diagnostic tests for neurological infections in central Africa. Lancet Infect Dis 13(6):546-558

Zhang Y, Wang Z, Chen H, Chen Z, Tian Y (2014) Antioxidants: potential antiviral agents for Japanese encephalitis virus infection. Int J Infect Dis 24:30-36 